\title{
Assessment of slope instability and its impact on land status: a case study from Central Himalaya, India
}

\author{
Anita Pande* \\ Department of Geography, Kumaun University, Nainital, India, * anita.ku.ntl@gmail.com
}

\begin{abstract}
Tectonic instability, geological sensitivity along with human intrusion in Himalaya has greatly exacerbated the occurrence of hazardous situation. Dynamics of slope instability have been evaluated under three processes leading to geomorphic instability, viz. i. erosion ii. mass wasting and iii. anthropogenic. Their causative factors have been identified under Ghuniyoli Gad watershed. The measurement of the intensity, magnitude and nature of instability factors were done within the units of $1 \mathrm{~km}^{2}$ under 21 units of watershed. Each unit was evaluated in terms of type, extent and corresponding degree of instability along with their potential assessment. The stage of erosion reveals that Ghuniyoli Gad watershed experiences instability. Maximum units fall under instability of degree 1 and degree 2 (38\% and 38\%) while minimum units belong to instability of degree $4(4.76 \%)$. The instability of degree 3 contributes only about $19.04 \%$. Appropriate mitigation measures to overcome hazardous calamities are needed to be introduced therein.
\end{abstract}

Key words: slope instability, erosion hazards, mass wasting hazards, anthropogenic hazards, potential instability/degree of instability, Himalaya

\section{Introduction}

Himalaya is the greatest physical identity of the Earth but fragile enough under physical and human stress. Combined action of the two is resulting in environmental degradation which has now become a global concern (Kienholz et al. 1983, 1984, Byers 1985, Zimmerman et al. 1986). The strategies for development, therefore, for Himalaya should be strictly with the nature, local resource base, socio-economic needs and aspirations of the people.

The tectonic sensitivity of Himalayan territory contributes significantly for the determination of landslide hazard and other land degradational processes (Valdiya 1985, 1987, Bartararya, Valdiya 1989, Rautela 2001, Pande et al. 2002, Chandel, Brar 2010, Chandel et al. 2011, Pande 2013). The anthropogenic processes have not only accelerated hazardous processes but also exposed human lives to greater risk (Bhandari, Gupta 1985, Bhandari 1988, Haigh et al. 1995, Singh 1998, Sah, Mazari 1998, 2007, Barnard et al. 2001, Cole, Sinclair 2002, Gardner, Saczuk 2004, Gardner, Dekens 2007, Sharma 2006, Tarantino et al. 2007, Starkel 2010). Himalaya is highly sensitive to changes in hydrological and climatic aspects which ultimately effects mountain environments development and sustainability (IPCC 2001, Eriksson 2006). The severe rainstorm was believed to be capable of triggering widespread landslides (Chen, Lee, 2003). The Earthquake triggered landslides are highly concentrated in specific zones associated with the lithology, structure, geomorphology, topography and human presence (Keefer 1994, 2002, Owen et al. 2008, Sato, Harp 2009, Yin et al. 2009). The mass-movement classification problem has been more complex than it has for many other types of extreme natural phenomena (Alexander 2008). Different researches provided model being able to identify those areas in greater risk of slope failure, and to differentiate between stable and landslide-prone ground (Mason, Rosenbaum 2002, Liu et al. 2004, Fourniadis et al. 2007). Spatial data for the assessment of landslide susceptibility, hazard, and vulnerability is of prime concern for hazard mapping (Van Westen et al. 2008).

The primary objective of the present study is to estimate the geomorphic hazards in the Himalayan environment and to determine the factors (natural or man-induced) those lead to changes in geomorphic stability so prediction can be made for future damage. 


\section{Study area}

The Ghuniyoli Gad watershed $\left(10.22 \mathrm{~km}^{2}\right)$ was selected for study (Fig. 1). The Ghuniyoli Gad is fourth order stream, tributary of fifth order Jaigan river. The Jaigan watershed $\left(150 \mathrm{~km}^{2}\right)$ extends in between the latitudes of $29^{\circ} 39^{\prime} 5^{\prime \prime} \mathrm{N}$ to $29^{\circ} 47^{\prime} 25^{\prime \prime} \mathrm{N}$ to and the longitudes of $79^{\circ} 41^{\prime} 45^{\prime \prime} \mathrm{E}$ to $79^{\circ} 53^{\prime} 40^{\prime \prime}$ E. Administratively it lies in Almora and Bageshwar Districts of Uttarakhand. It is a part of the greatest Sarju-Kali drainage system of Central Himalaya.

\section{Data base and methodology}

The climate of the area has been assessed on the basis of nearest meteorological stations: Bhainsiyachhana (700 $\mathrm{m}$ a.s.l.) and Kanarichhina (1,000 m a.s.l.) located in valley, and Dhaulchhina (1,900 $\mathrm{m}$ a.s.l.) on ridge (Fig. 1). The base data was collected by the Author (Pande 1998). Detailed geological and structural maps of Valdiya (1980) were used to identify lithological formations, thrust, fault and fold, verifications of which were done during field studies. Base maps of relief, drainage, land use, vegetation were prepared with the help of SOI Topographical sheet No. $53 \mathrm{O} / 14$. The stream ordering was done by Strahler's (1964) stream segment method. The stages of geomorphic development of watershed were derived by Strahler's (1952) percentage hypsometric curve. Area computation and length measurements were done by grid method and rotameter/opisometer.

The approach of present study was based on the standards provided by United Nations University
MHM project on Kathmandu - Kakani area, Nepal (Kienholz et al. 1984). $1 \mathrm{~km}^{2}$ grid was selected as basic unit for the field observations and measurement of hazards. GPS is used for the geographical location and measurement of elevation of affected localities. Each grid was designated by code number (for example A1, see Fig. 5). And the observation sites were identified within specific grid, the numbers of which were dependent on the intensity, magnitude and nature of instability factors under specific land use. The criterion selected for the establishment of observational sites were boarder between depressions of stream and open slope, accumulation of certain types of damage, change of general slope angle, change in land use and change in slope direction.

Each basic unit of $1 \mathrm{~km}^{2}$ was evaluated in terms of the types of instability and the causative factors responsible for the specific hazard. Thus a succeeding map of geomorphic hazards was fabricated. The derived map provides a scenario for the types and corresponding degrees of confirmed/inferred instability along with area coverage. The hazard map was again evaluated in terms of probable damage and the derived map constitutes types and corresponding degrees of suspected instability.

The hazard of surficial erosion (se) was noticed along the terraces under cultivation/agriculture practices. Thus, surficial erosion was denoted by the entire cultivated land that's why the number of observation sites was not mentioned in the Table 3. The geomorphic hazard was evaluated also excluding surficial erosion because of the fact that surficial erosion was mapped but not assessed as hazards like other processes since it was not considered as direct

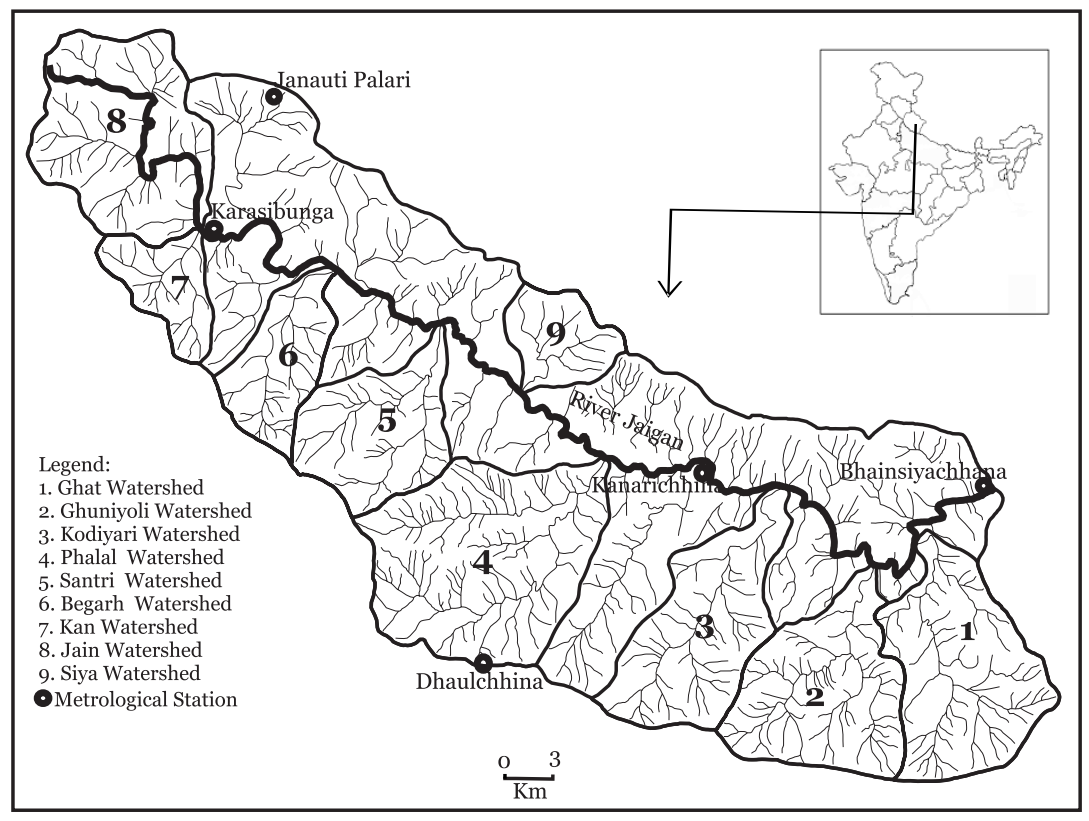

Fig. 1. Location of study area. No. 2 - the Ghuniyoli Gad watershed 
danger. The $1^{\text {st }}, 2^{\text {nd }}$ and $3^{\text {rd }}$ order seasonal streams marked on S.O.I. topographical sheets of 1963 and verified during field survey were designated as old gullies. The hazard of old gully erosion (go) indicated the erosion along these preexisted (before present survey) gullies. The new gullies are surveyed during field work which was supposed to be created after 1963 as those were not present in SOI topographical sheets. The hazard of new gully erosion (gn) was indicated by the erosion along these newly created gullies.

\section{Results}

\section{Climate setting}

The mean monthly air temperature ranges between $15^{\circ} \mathrm{C}$ to $30^{\circ} \mathrm{C}$ in valley while $12^{\circ} \mathrm{C}$ to $23^{\circ} \mathrm{C}$ on the ridge (Table 1). The mean maximum air temperature reach $36^{\circ} \mathrm{C}$ and to $28^{\circ} \mathrm{C}$ respectively. The mean minimum air temperature ranges in between $8^{\circ} \mathrm{C}$ to $26^{\circ} \mathrm{C}$ in valley while $4^{\circ} \mathrm{C}$ to $18^{\circ} \mathrm{C}$ on the ridge. The coldest month is January while warmest month is June. The annual rainfall totals reach $1,126 \mathrm{~mm}$ in valleys and $994 \mathrm{~mm}$ in hill tops. The maximum rainfalls occur from June to September, when monthly totals are from 125 to $241 \mathrm{~mm}$. Minimum monthly totals are in November and range from $8 \mathrm{~mm}$ (valley area) to $13 \mathrm{~mm}$ (hill tops). Winter rainfalls are insignificant.

\section{Geological setting}

The watershed is built by the rocks of Augun Gneiss formation. This unit comprises granitic gneiss, chlorite-sericite schist. The North Almora Thrust (NAT) and regional anticline followed by the Jaigan River are two key factors completely controlled modern topography of the studied catchment. The NAT passes through the northern most part of the Ghuniyoli watershed (out of the watershed). Along the thrust the rocks are powered. The tectonic activity of this zone is marked by immature topography and unlimited landslides of valley sides. The tight overturned northerly dipping Jaigan anticline is followed by Jaigan River, trending NNW-SSE. The unusual development of river terraces shows active nature of this anticline. The existence of Jaigan River along the axial trace of the anticline creates a reversal topography forming an anticlinal valley and synclinal ridge. The most noticeable point was that Ghuniyoli Gad flows from south to north and ultimately meets Jaigan River where the axis of anticline exists (Valdiya 1980).

\section{Geomorphological setting}

\section{Relief}

Wide valleys, with slopes developed up to sharp spurs and extended ridges are characteristic landforms in the area (Fig. 2). The altitude ranges between $840 \mathrm{~m}$ to $2,346 \mathrm{~m}$ a.s.l. and $34.14 \%$ of the area is located above $2,100 \mathrm{~m}$ a.s.l. while only $6.95 \%$

Table 1. Characteristics of climate in Ghuniyoli Watershed based on meteorological data 1995-1998

\begin{tabular}{|c|c|c|c|c|c|c|c|c|c|c|c|c|c|c|c|}
\hline \multirow{4}{*}{ Months } & \multicolumn{15}{|c|}{ Meteorological station } \\
\hline & \multicolumn{5}{|c|}{$\begin{array}{c}\text { Bhainsiyachhana } \\
\text { Valley-Station (700 m a.s.l.) }\end{array}$} & \multicolumn{5}{|c|}{$\begin{array}{c}\text { Kanarichhina } \\
\text { Valley-Station (1,000 m a.s.l.) }\end{array}$} & \multicolumn{5}{|c|}{$\begin{array}{c}\text { Dhaulchhina } \\
\text { Ridge-Station (1,900 m a.s.l.) }\end{array}$} \\
\hline & 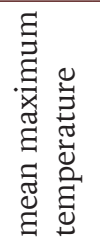 & 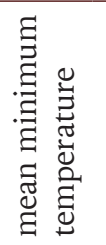 & 㫕 & 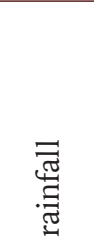 & 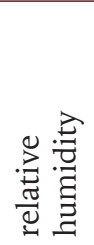 & 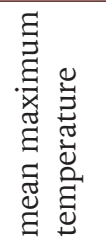 & 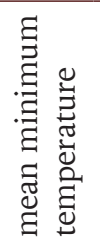 & 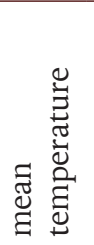 & 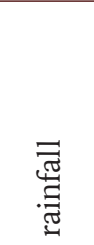 & 怘: & 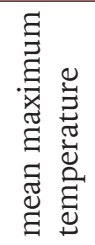 & 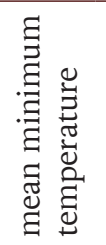 & 㫕 & 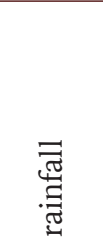 & 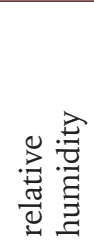 \\
\hline & & {$\left[{ }^{\circ} \mathrm{C}\right]$} & & {$[\mathrm{mm}]$} & {$[\%]$} & & {$\left[{ }^{\circ} \mathrm{C}\right]$} & & {$[\mathrm{mm}]$} & {$[\%]$} & & {$\left[{ }^{\circ} \mathrm{C}\right]$} & & {$[\mathrm{mm}]$} & {$[\%]$} \\
\hline January & 22.5 & 7.6 & 15.0 & 54 & 75 & 23.1 & 8.1 & 15.6 & 30 & 70 & 21.7 & 4.1 & 12.9 & 41 & 54 \\
\hline February & 24.4 & 9.8 & 17.1 & 76 & 79 & 23.6 & 10.2 & 16.9 & 48 & 69 & 20.4 & 4.9 & 12.6 & 32 & 63 \\
\hline March & 32.7 & 13.4 & 28.0 & 24 & 70 & 31.9 & 14.6 & 23.2 & 46 & 64 & 22.7 & 9.3 & 16.0 & 25 & 62 \\
\hline April & 33.5 & 17.1 & 25.3 & 40 & 67 & 34.0 & 20.0 & 27.0 & 87 & 72 & 24.1 & 12.5 & 18.3 & 69 & 66 \\
\hline May & 35.2 & 20.6 & 27.9 & 28 & 62 & 35.1 & 21.6 & 28.4 & 28 & 59 & 28.3 & 15.5 & 21.9 & 19 & 66 \\
\hline June & 35.5 & 22.5 & 29.0 & 86 & 65 & 36.1 & 25.1 & 30.6 & 167 & 73 & 26.0 & 15.8 & 20.9 & 194 & 87 \\
\hline July & 34.8 & 25.6 & 30.2 & 208 & 84 & 34.5 & 26.0 & 30.2 & 174 & 83 & 27.0 & 18.5 & 22.7 & 156 & 88 \\
\hline August & 33.1 & 24.3 & 28.7 & 261 & 85 & 34.1 & 21.0 & 27.6 & 277 & 87 & 26.7 & 17.8 & 22.2 & 241 & 88 \\
\hline September & 34.0 & 22.9 & 28.5 & 216 & 86 & 35.1 & 18.9 & 27.0 & 190 & 83 & 25.8 & 16.6 & 21.2 & 125 & 84 \\
\hline October & 28.6 & 17.5 & 23.1 & 31 & 81 & 33.1 & 19.2 & 26.2 & 48 & 80 & 25.1 & 12.0 & 18.6 & 46 & 64 \\
\hline November & 28.3 & 12.6 & 20.4 & 0 & 77 & 31.8 & 16.4 & 24.1 & 8 & 77 & 25.4 & 9.6 & 17.5 & 13 & 55 \\
\hline December & 25.1 & 9.4 & 17.2 & 8 & 74 & 27.1 & 10.9 & 19.0 & 23 & 71 & 23.3 & 6.4 & 14.8 & 33 & 55 \\
\hline
\end{tabular}




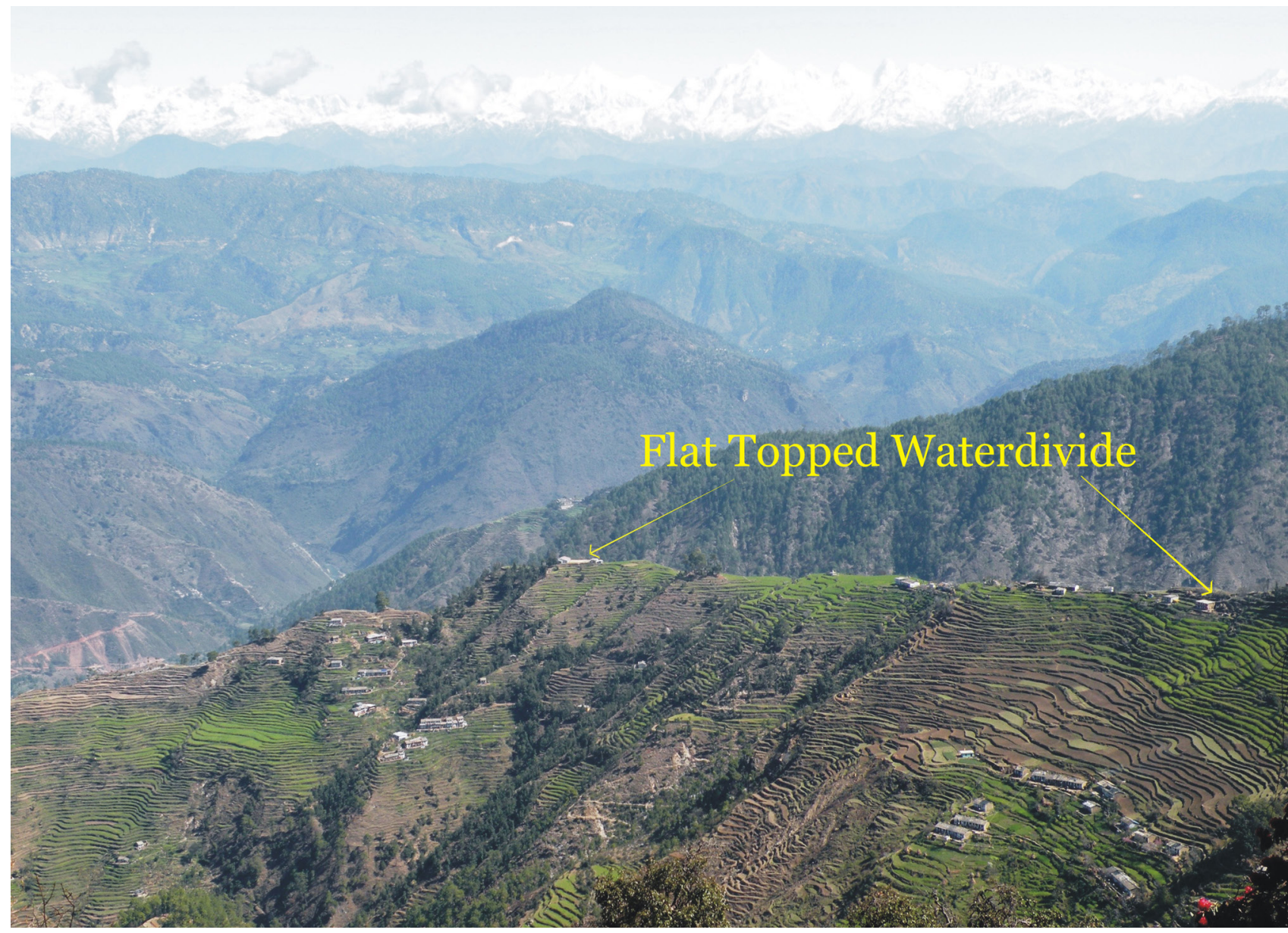

Fig. 2. Sharp ridges and wide valleys of the study area. Location of settlement along flat topped waterdivide in Thala Village

below $1,500 \mathrm{~m}$ a.s.1. Relative relief ranges in between $420 \mathrm{~m}$ to $760 \mathrm{~m}$. Maximum area (51.20\%) falls under below $550 \mathrm{~m}$ zone while minimum area $(3.52 \%)$ is covered by above $650 \mathrm{~m}$ zone. Dissection index ranges in between 0.18 to 0.44 . Maximum area $(35.71 \%)$ falls under 0.20 to 0.25 zone followed by 0.25 to 0.30 zone, i.e. $33.66 \%$ while minimum area $(3.73 \%)$ is covered by above 0.40 zone. Average slope ranges in between $20^{\circ}$ to $35^{\circ}$. Maximum area (52.54\%) falls under $30^{\circ}$ to $35^{\circ}$ zone while $47.46 \%$ of the area is covered by below 300 zone. The steepest slope of the watershed belongs to the headward part of the watershed (Fig. 3). The watershed is characterized by three types of soils: Regolith, Alluvial and Podzol. Regolith soils develop due to high degradational processes along the slopes. The valleys possess the alluvial soil by the aggradational process of Ghuniyoli Gad stream. The composition of this soil is sand and pebbles. The colour and size of this soil are brown and granular respectively with a nature of loamous. Because of good aeration and water holding capacity it is best soil for cultivation. Podzol soils occur under the oak forest cover where deceased lichen and moss provide it the podzolic nature.
Stage of erosion

The geomorphic evolution (erosion stage) of the watershed was assessed under varying altitudinal variations (Table 2). Further the erosion was evaluated under different land use, i.e. inact land, cultivated land and forest land while barren land was not available in the watershed (Fig. 4A, B, C).

\section{Stage of erosion, altitude and the watershed}

The watershed is under severe land degradation. Out of total Ghuniyoli watershed area, $36.16 \%$ area attained stress as a result of erosion. The zone of critical height was 1,800-1,900 $\mathrm{m}$ a.s.l. above which the erosion was the most strong. The watershed attained inequilibrium (youthful) stage as per the hypsometric integral (63.84\%). In reference to area under intense erosion, the altitudinal zone of 2,200 to 2,300 $\mathrm{m}$ a.s.l. contributes maximum area (6.34\%) while 900 to $1,000 \mathrm{~m}$ a.s.l. zone constitutes minimum area $(0.04 \%)$ out of the area of the watershed. In reference to area under insignificant erosion, the altitudinal zone of 900 to $1,000 \mathrm{~m}$ a.s.1. contributes maximum area $(6.96 \%)$ while the altitudinal zone of above $(>)$ $2,300 \mathrm{~m}$ a.s.1. constitutes minimum area $(0.09 \%)$ out of the area of the watershed. 


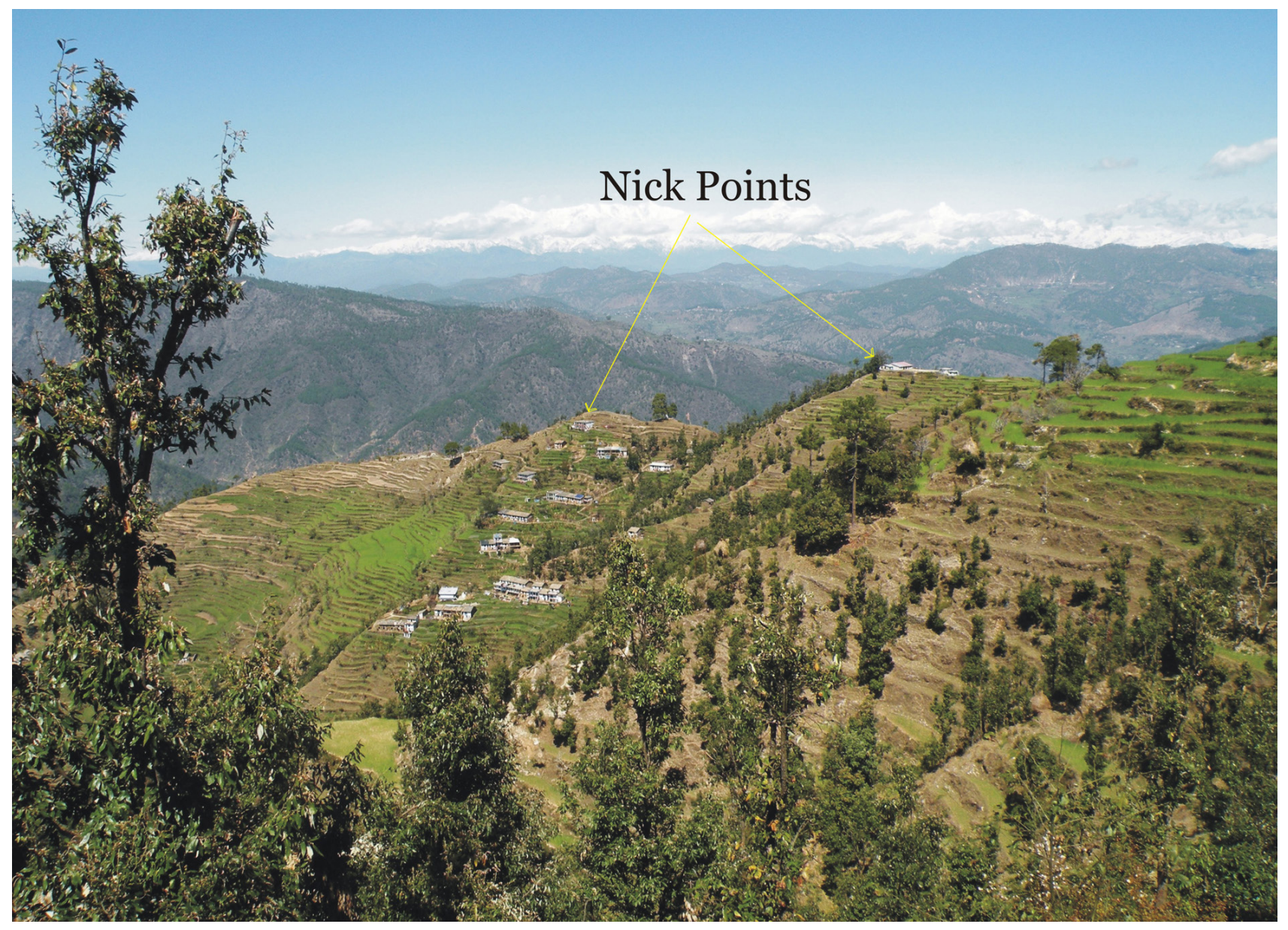

Fig. 3. Nick points along the water divide in Ghuniyoli watershed

Table 2. Ghuniyoli Watershed: Variability in stage of erosion (EI, HI) under varying altitude

\begin{tabular}{|c|c|c|c|c|c|c|c|c|c|}
\hline \multirow{4}{*}{$\begin{array}{l}\text { Altitude } \\
{[\mathrm{m} \text { a.s.l. }]}\end{array}$} & \multicolumn{3}{|c|}{ Intact Watershed Scenario } & \multicolumn{3}{|c|}{ Cultivated Land Scenario } & \multicolumn{3}{|c|}{ Forest Land Scenario } \\
\hline & $\begin{array}{c}\text { intensely } \\
\text { eroded area }\end{array}$ & $\begin{array}{c}\text { insignificantly } \\
\text { eroded area }\end{array}$ & $\begin{array}{l}\text { total } \\
\text { area }\end{array}$ & $\begin{array}{c}\text { intensely } \\
\text { eroded area }\end{array}$ & $\begin{array}{c}\text { insignificantly } \\
\text { eroded area }\end{array}$ & $\begin{array}{l}\text { total } \\
\text { area }\end{array}$ & $\begin{array}{l}\text { intensely } \\
\text { eroded area }\end{array}$ & $\begin{array}{c}\text { insignificantly } \\
\text { eroded area }\end{array}$ & $\begin{array}{l}\text { total } \\
\text { area }\end{array}$ \\
\hline & EI & $\mathrm{HI}$ & & EI & $\mathrm{HI}$ & & EI & $\mathrm{HI}$ & \\
\hline & \multicolumn{9}{|c|}{$[\%]$} \\
\hline$<900$ & 0.00 & 4.00 & 4.0 & 0.00 & 5.00 & 5.0 & 0.00 & 3.00 & 3.0 \\
\hline $900-1,000$ & 0.04 & 6.96 & 7.0 & 0.05 & 6.95 & 7.0 & 0.04 & 5.96 & 6.0 \\
\hline $1,000-1,100$ & 0.12 & 5.88 & 6.0 & 0.08 & 7.92 & 8.0 & 0.14 & 6.86 & 7.0 \\
\hline $1,100-1,200$ & 0.31 & 6.69 & 7.0 & 0.13 & 7.87 & 8.0 & 0.39 & 6.61 & 7.0 \\
\hline $1,200-1,300$ & 0.52 & 5.98 & 6.5 & 0.34 & 7.66 & 8.0 & 0.68 & 6.32 & 7.0 \\
\hline $1,300-1,400$ & 0.75 & 5.75 & 6.5 & 0.57 & 6.43 & 7.0 & 0.79 & 5.21 & 6.0 \\
\hline $1,400-1,500$ & 1.05 & 5.95 & 7.0 & 0.92 & 7.08 & 8.0 & 1.20 & 5.80 & 7.0 \\
\hline $1,500-1,600$ & 1.27 & 4.73 & 6.0 & 1.29 & 6.71 & 8.0 & 1.67 & 5.33 & 7.0 \\
\hline $1,600-1,700$ & 2.10 & 4.90 & 7.0 & 2.05 & 4.95 & 7.0 & 1.86 & 4.14 & 6.0 \\
\hline $1,700-1,800$ & 2.91 & 4.09 & 7.0 & 4.12 & 3.88 & 8.0 & 2.60 & 4.40 & 7.0 \\
\hline $1,800-1,900$ & 3.20 & 2.80 & 6.0 & 5.92 & 2.08 & 8.0 & 3.05 & 3.95 & 7.0 \\
\hline $1,900-2,000$ & 4.47 & 2.53 & 7.0 & 7.06 & 0.94 & 8.0 & 3.69 & 3.31 & 7.0 \\
\hline $2,000-2,100$ & 5.17 & 1.83 & 7.0 & 7.59 & 0.41 & 8.0 & 3.88 & 2.12 & 6.0 \\
\hline $2,100-2,200$ & 5.00 & 1.00 & 6.0 & 1.97 & 0.03 & 2.0 & 5.34 & 1.66 & 7.0 \\
\hline $2,200-2,300$ & 6.34 & 0.66 & 7.0 & N.A. & N.A. & N.A. & 6.03 & 0.97 & 7.0 \\
\hline$>2,300$ & 2.91 & 0.09 & 3.0 & N.A. & N.A. & N.A. & 2.85 & 0.15 & 3.0 \\
\hline
\end{tabular}

N.A. - not available. 


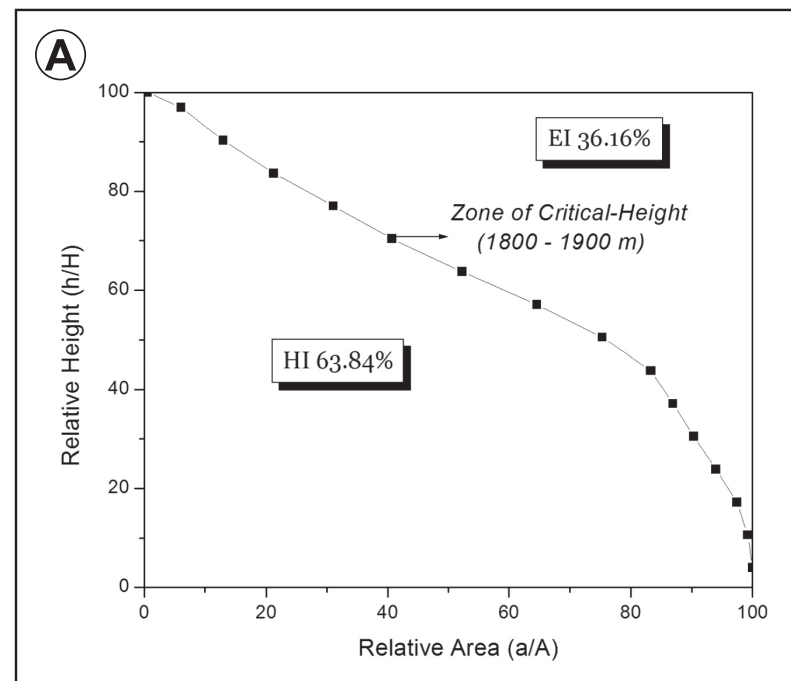

(B)

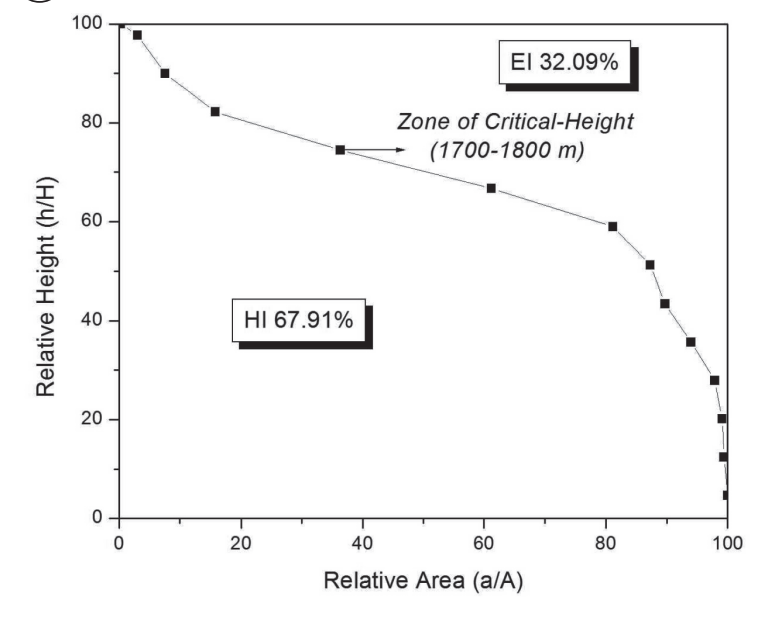

(C)

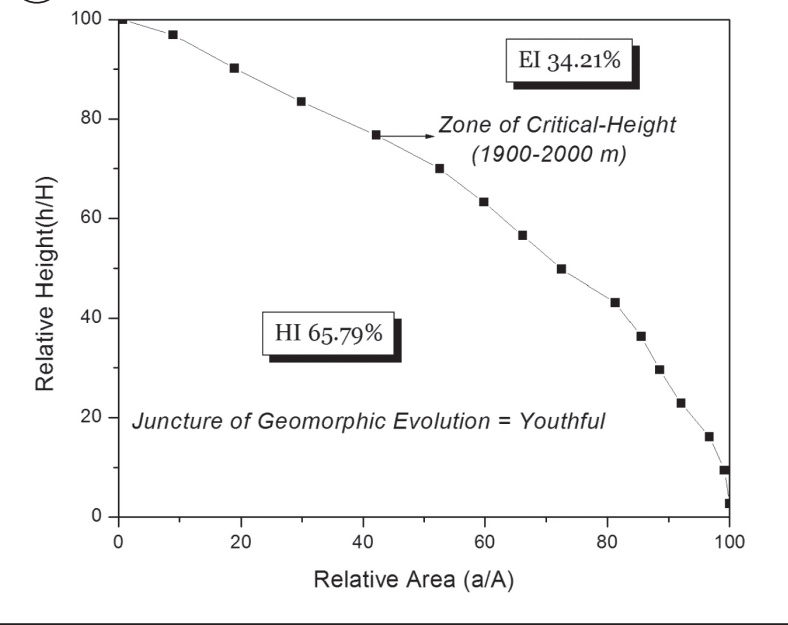

Fig. 4. Stages of erosion and land use in the the Ghuniyoli Gad watershed

A - inact (entire) watershed, B - cultivated land, C - forest land. $\mathrm{H}$ - total height of the watershed, $\mathrm{h}$ - height between two successive contours, a - area between two successive contours, A - total area of the watershed, HI - Hypsometric Integral , EI Erosion Integral
Stage of erosion, altitude and the cultivated land

The cultivated land of watershed was under the severe stress of erosion. Out of total cultivated land, Ghuniyoli watershed possesses $32.09 \%$ area under serious threat to erosion. Over the entire cultivated land, the zone of critical height was 1,800 to $1,900 \mathrm{~m}$ a.s.l. above which erosion was intense. The hypsometric integral (67.91\%) determined the stage of inequilibrium (youthful) for cultivated land of the watershed. In reference to area of the cultivated land under intense erosion, the altitudinal zone of 2,000 to 2,100 $\mathrm{m}$ a.s.l. contributes maximum area $(7.59 \%)$ while the altitudinal zone of 900 to $1,000 \mathrm{~m}$ a.s.l. attains minimum area $(0.05 \%)$ out of the area of cultivated land of the watershed. In reference to area of the cultivated land under insignificant erosion, the altitudinal zone of 1,000 to $1,100 \mathrm{~m}$ a.s.l. contributes maximum area (7.92\%) while the altitudinal zone of 2,100 to 2,200 $\mathrm{m}$ a.s.l. constitutes minimum area $(0.03 \%)$ out of the area of cultivated land of the watershed.

\section{Stage of erosion, altitude and forest land}

The forest land was also under the crucial problem of erosion. Out of total forest land, Ghuniyoli watershed attained $34.21 \%$ area under severe stress as a result of erosion. Over the entire forest area of watershed, the zone of critical height was 1,900 to 2,000 $\mathrm{m}$ a.s.l. above which erosion was acute. The hypsometric integral $(65.79 \%)$ ascertained the stage of inequilibrium (youthful) for forest land of the watershed. In reference to the area of the forest land under intense erosion, the altitudinal zone of 2,200 to $2,300 \mathrm{~m}$ a.s.l. contributes maximum area $(6.03 \%)$ while the altitudinal zone of 900 to $1,000 \mathrm{~m}$ a.s.l. constitutes minimum area $(0.04 \%)$, out of the area of forest land of the watershed. In reference to the area of the forest land under insignificant erosion, the altitudinal zone of 1,000 to $1,100 \mathrm{~m}$ a.s.l. contributes maximum area $(6.86 \%)$ while the altitudinal zone of above 2,300 $\mathrm{m}$ a.s.l. constitutes minimum area (15\%), out of the area of forest land of the watershed.

\section{Land use}

The Ghuniyoli Gad watershed possesses two types of land use/land cover. $32.29 \%$ area falls under cultivated land while rest $67.71 \%$ area is covered by forest (Fig. 5). Field observations reveal that land use pattern is controlled by geomorphic and climatic conditions. The part of the watershed at altitude from 800 to $1,200 \mathrm{~m}$ a.s.l. is covered by forest because the lower part of watershed posses narrow valleys with steep slopes. The upper part has extended valley and moderate slope, but at altitude from 1,800 to $2,346 \mathrm{~m}$ a.s.l. extreme climatic conditions (dry) do not allow the habitation and agricultural processes therefore this area is also under forest. Thus middle part at al- 


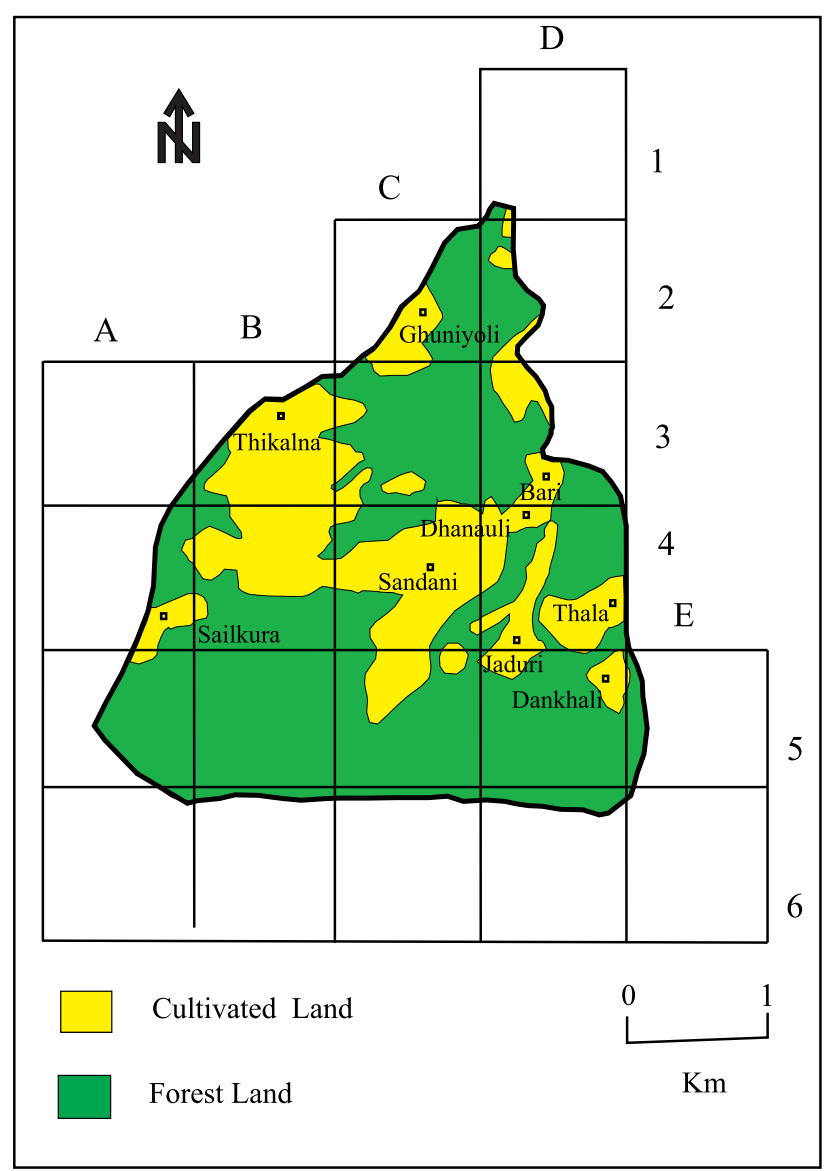

Fig. 5. Study units and land use in the Ghuniyoli Gad watershed

titude from 1,200 to $1,800 \mathrm{~m}$ a.s.l. is under intensive settlement and agricultural processes owing to appealing geomorphic and climatic (humid) conditions.

\section{Cultivated land}

Cultivation commences from the river banks (irrigated alluvial terraces) and continues towards uphill (dry man-made terraces) as the population grows. All the cultivation is carried out in terraced landform. Terracing is an indigenous method of adapting hill-sides for cultivation and only effective means of control soil erosion. The uphill terraces are locally known as Upraon land (dry land) and the farming is known as dry-farming while the river bank terraces are locally known as Talaon land (irrigated land) and the farming is known as wet-farming. The uplands, like the irrigated plots, produce two harvests. The kharif or autumn crop is known as the chaumasiya kheti, and the rabi or spring crop as the huniya or winter crop. Main crops of Kharif are madua (Eleusine coracana), paddy, amaranthus (Amaranths penictata), buckwheat (ogal), kauni (Panicum italicum), jhangora (Oplismenus frumentaceus) and mixed crop of pulses (bhat, gahat, rans), amaranthus and maize are grown side by side. Chilies and turmeric are the basic commercial crops of uplands dry-farm- ing system. Under rabi crops, main crops are wheat, barley and mustard. In Talaon land, paddy is the only crop which is grown in kharif (autumn crop), which is the most important staple in these lands and the cultivator devotes all his energies to the production of this crop. Rabi (spring crop) in these valley bottoms consists of wheat, barley, lentils, mustard and flax.

\section{Forest land}

The Himalayan sub-tropical pine forest, oak forest, moist mixed and deciduous forest were the characteristic feature of the area. Field study indicates that pine forest was very vulnerable to erosion (intensive gully erosion) due to thin soil cover and shallow roots of the tree.

\section{Settlement}

Settlement area is in scattered form only within the cultivated land. Density of population is found about 18 persons per $\mathrm{km}^{2}$. The population of the watershed is confined to $32.29 \%$ of the total geographical area of the watershed, resulting in a very high degree of population concentration. Although the general density of population is very low, in case of population pressure per unit cultivated land, it is very high almost equal to Gangetic plain, i.e. about 545 persons per $\mathrm{km}^{2}$. In general, the area of the watershed depicts that the expansion has taken place mostly in the outwardly sloping land in mid and upper elevations of the watershed which has contributed in exaggerating hazardous geomorphic processes.

\section{Geomorphic hazards}

Eleven types of geomorphic hazards were identified in the Ghuniyoli watershed within twenty one study units (Fig. 6, Table 3) which were grouped into three major hazards: a/ erosion hazards (surficial erosion (se), gully erosion (erosion in old gully (go), erosion in new gully(gn), gully-induced terrace collapsing (gc), flood-induced terrace collapsing (fc), accumulation of water transported material (aw)), b/ mass wasting hazards (debris flows (df), landslides (ls), soil creeping (sc)), c/ anthropogenic hazards (stone quarry (sq), man-induced terrace collapsing (mc)).

\section{Erosion hazards}

Surficial erosion (se) is significant in the units with cultivation especially in upper reaches of valley slopes with terraces (Fig. 7). This is observed in fourteen units (Table 3, Fig. 6). Gully erosion is significant under 14 units out of total 21 units of the watershed 


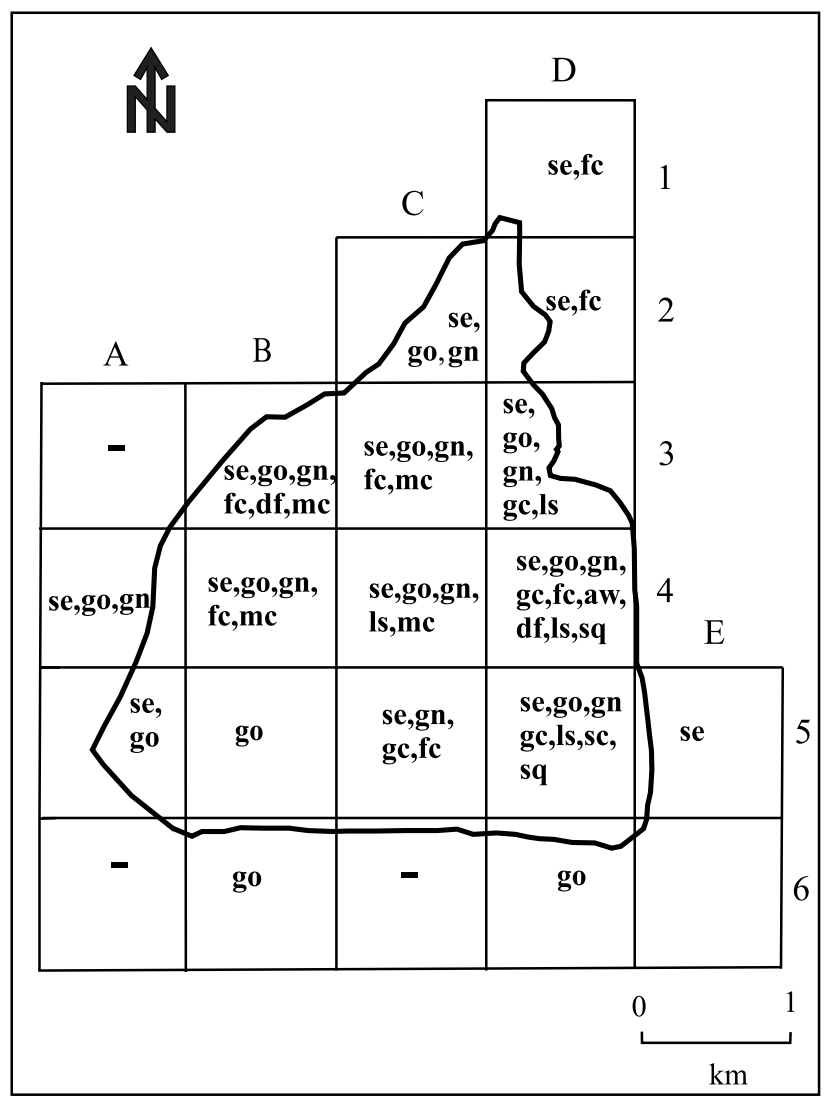

which proves the extent of erosion and instability of the area (Table 3, Fig. 6). It was active in old erosional gully in 13 units while in fresh erosional gullies in 10 units only. The gully erosion was prominent in forest area along steeply sloping forest (Fig. 8). Gully induced terrace collapsing was experienced by 4 units (Fig. 6) located within the cultivated land. In the others the new gullies were created in pine forest. Efforts have been done by the inhabitants to manage their cultivated land, yet their efforts were proved fruitless due to geological sensitivity of the terrain consequently the reconstructed terraces were not maintained. Flood induced terrace collapsing was experienced 2 units (Table 3, Fig. 6). Accumulation of water transported material upon cultivated land was found only in one unit (4D) (Table 3, Fig. 6). The debris material transported through new created gully from pine forest area was accumulated upon cultivated land on area of $3,000 \mathrm{~m}^{2}$ and disturbed the continuity of agricultural terraces.

Fig. 6. Types and corresponding degree of confirmed/inferred instability

se - surficial erosion, go - erosion in old gully, gn - erosion in new gully, gc - gully induced collapsing of terraces, fc - flood induced collapsing of terraces, aw - accumulation of water transported material, df - debris flow, ls - landslide, sc - soil creeping, sq - stone quarry, mc - man-induced collapsing of terraces

Table 3. Ghuniyoli Watershed: types and corresponding degree of confirmed / inferred and suspected instability

\begin{tabular}{|c|c|c|c|c|c|c|}
\hline \multirow{2}{*}{$\begin{array}{l}\text { Basic } \\
\text { Units }\end{array}$} & \multirow{2}{*}{$\begin{array}{l}\text { Number of observation } \\
\text { sites of particular type } \\
\text { of instability }\end{array}$} & \multicolumn{2}{|l|}{ Confirmed/Inferred } & \multicolumn{2}{|c|}{ Land use (\% of area) } & \multirow{2}{*}{$\begin{array}{l}\text { Suspected } \\
\text { degree of } \\
\text { instability }\end{array}$} \\
\hline & & type of instability & degree & cultivated & forest & \\
\hline $1 \mathrm{D}$ & $*, 2$ & se, fc. & $1,2 b$ & 33.33 & 66.67 & $\mathrm{D}_{1}$ \\
\hline $2 \mathrm{C}$ & $*, 1,7$. & se, go, gn. & $1,2 b$ & 29.47 & 70.53 & $\mathrm{D}_{2}$ \\
\hline $2 \mathrm{D}$ & $*, 1$ & se, fc. & $1,2 b$ & 24.17 & 75.83 & $\mathrm{D}_{2}$ \\
\hline $3 \mathrm{~A}$ & N.A. & N.A. & 1 & N.A. & 100.00 & $\mathrm{D}_{1}$ \\
\hline $3 \mathrm{~B}$ & $*, 6,2,2,1,10$ & se, go, gn, fc, df, mc. & 1 & 87.27 & 12.73 & $\mathrm{D}_{2}$ \\
\hline $3 \mathrm{C}$ & $*, 9,5,3,2$ & se, go, gn, fc, mc. & $1,2 b$ & 15.87 & 84.13 & $\mathrm{D}_{2}$ \\
\hline $3 \mathrm{D}$ & $*, 5,3,5,1$ & se, go, gn, gc, ls. & 1 & 34.85 & 65.15 & $\mathrm{D}_{2}$ \\
\hline $4 \mathrm{~A}$ & *, 4, 3 & se, go, gn. & $1,2 b$ & 32.17 & 67.83 & $\mathrm{D}_{2}$ \\
\hline $4 \mathrm{~B}$ & $*, 11,7,6,4$ & se,go,gn,fc,mc. & 1 & 52.25 & 47.75 & $\mathrm{D}_{3}$ \\
\hline $4 \mathrm{C}$ & $*, 15,4,1,12$ & se,go,gn,ls,mc. & $1,2 b$ & 68.00 & 32.00 & $\mathrm{D}_{3}$ \\
\hline $4 \mathrm{D}$ & $*, 6,4,4,6,4,1,6,2$ & se, go, gn, gc, fc, aw, df, ls, sq. & $2 \mathrm{a}$ & 46.75 & 53.25 & $\mathrm{D}_{4}$ \\
\hline $5 \mathrm{~A}$ & $*, 4$ & se, go. & 1 & 02.86 & 97.14 & $\mathrm{D}_{2}$ \\
\hline $5 \mathrm{~B}$ & 10 & go. & 1 & N.A. & 100.00 & $\mathrm{D}_{2}$ \\
\hline $5 \mathrm{C}$ & $*, 6,20,7$ & se, gn, gc, fc. & $1,2 b$ & 19.00 & 81.00 & $\mathrm{D}_{3}$ \\
\hline $5 \mathrm{D}$ & $*, 9,2,8,2,1,1$ & se, go, gn, gc, ls, sc, sq. & $1,2 b$ & 14.25 & 85.75 & $\mathrm{D}_{3}$ \\
\hline $5 \mathrm{E}$ & *. & se & 0 & 08.82 & 91.18 & $\mathrm{D}_{1}$ \\
\hline $6 \mathrm{~A}$ & N.A. & N.A. & 0 & N.A. & 100.00 & $\mathrm{D}_{1}$ \\
\hline $6 \mathrm{~B}$ & 1. & go & 1 & N.A. & 100.00 & $\mathrm{D}_{2}$ \\
\hline $6 \mathrm{C}$ & NA & N.A. & 0 & N.A. & 100.00 & $\mathrm{D}_{1}$ \\
\hline $6 \mathrm{D}$ & 2. & go & 1 & N.A. & 100.00 & $\mathrm{D}_{2}$ \\
\hline $6 \mathrm{E}$ & N.A. & N.A. & 0 & N.A. & 100.00 & $\mathrm{D}_{1}$ \\
\hline
\end{tabular}

Type of instability: explanations of abbreviations see Fig. 6, Degree: 0 - no known instability, 1 - moderate instability, $2 \mathrm{a}-$ land may be irreversibly destroyed $2 \mathrm{~b}$ - arable land may be damaged, 3 - high instability; Suspected degree of instability - explanations see Fig. 15; N.A. Not Available. 


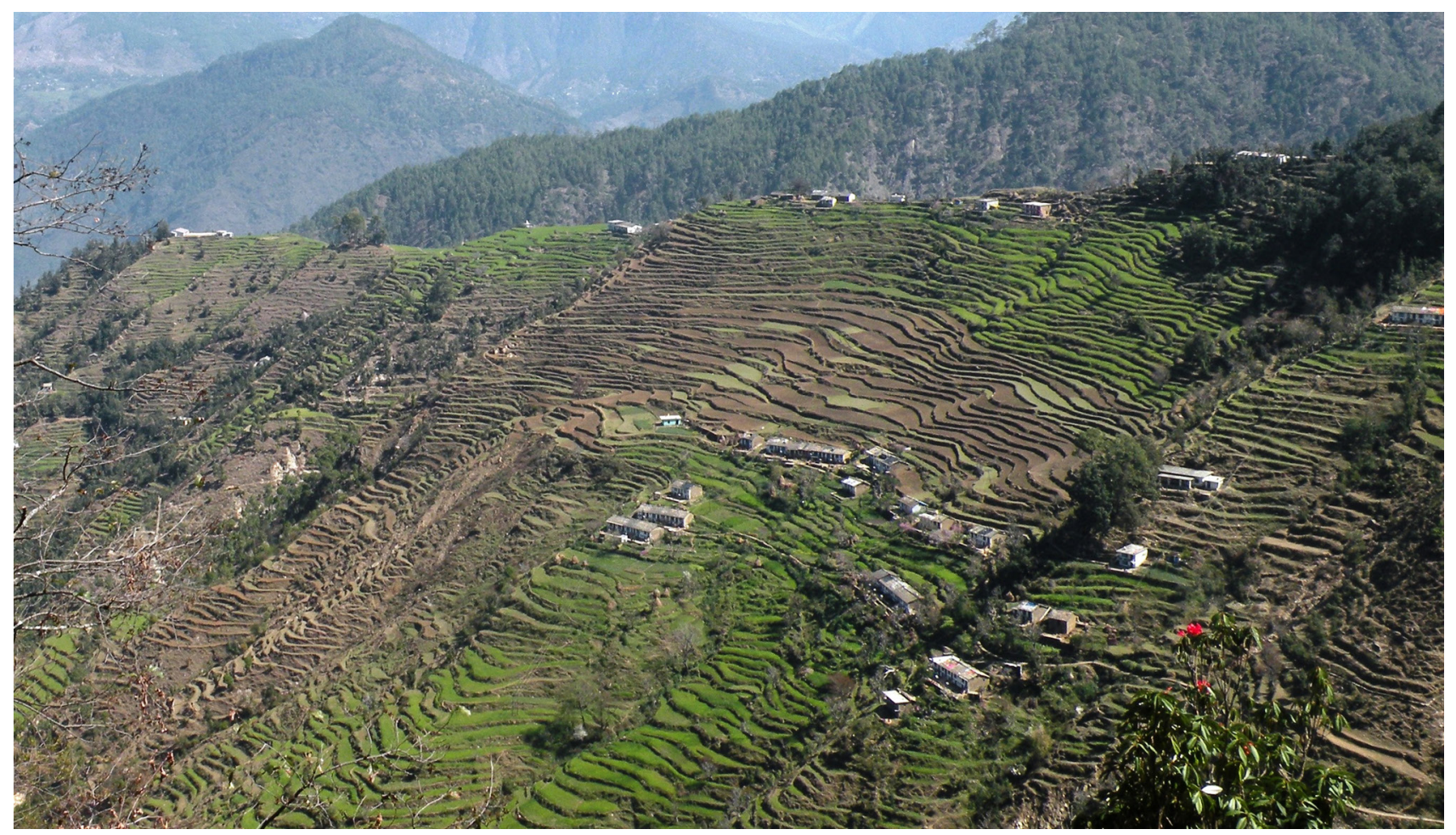

Fig. 7. Subsiding agricultural terraces along steep slope in Thala Village

\section{Mass wasting hazards}

Debris flows was observed in two units (Table 3, Fig. 6). In unit $3 \mathrm{~B}$ debris flow is studied in pine forest area located along Ghuniyoli Gad. The debris flow covers about 30,000 $\mathrm{m}^{2}$ area along steep (almost vertical slope) slope. Maximum debris was washed away by Ghuniyoli Gad stream and form a tonque with badland like topography. Debris flows are active each year during monsoons. Downslope the tonque cutting of pine forest along steep scarp were the observed causes of this hazard. In unit 4D, the debris flow was observed in grassy slope (Jaduri village) surrounded by sparse pine forest. An area of about $24 \mathrm{~m}^{2}$ was covered by this debris flow which was protected by check dams in its initial stage. The uppermost part of this debris flow was under the pressure of agricultural processes, thus exaggerating the vulnerability of the terrain.

Landsliding was experienced as a severe problem of the watershed. It was observed that almost each village of the watershed possesses active landslides which were located especially in the upper reaches of the watershed, though check dams were constructed along Jalia Gad (tributary of Ghuniyoli Gad). Reshaping of already constructed check dams indicate the continuous process of landsliding (cracks in houses, tilting of courtyard and fruit trees, break in the continuity of agricultural terraces, subsided houses (dislocation of houses from their original places) as a result of which the houses were removed to escape from

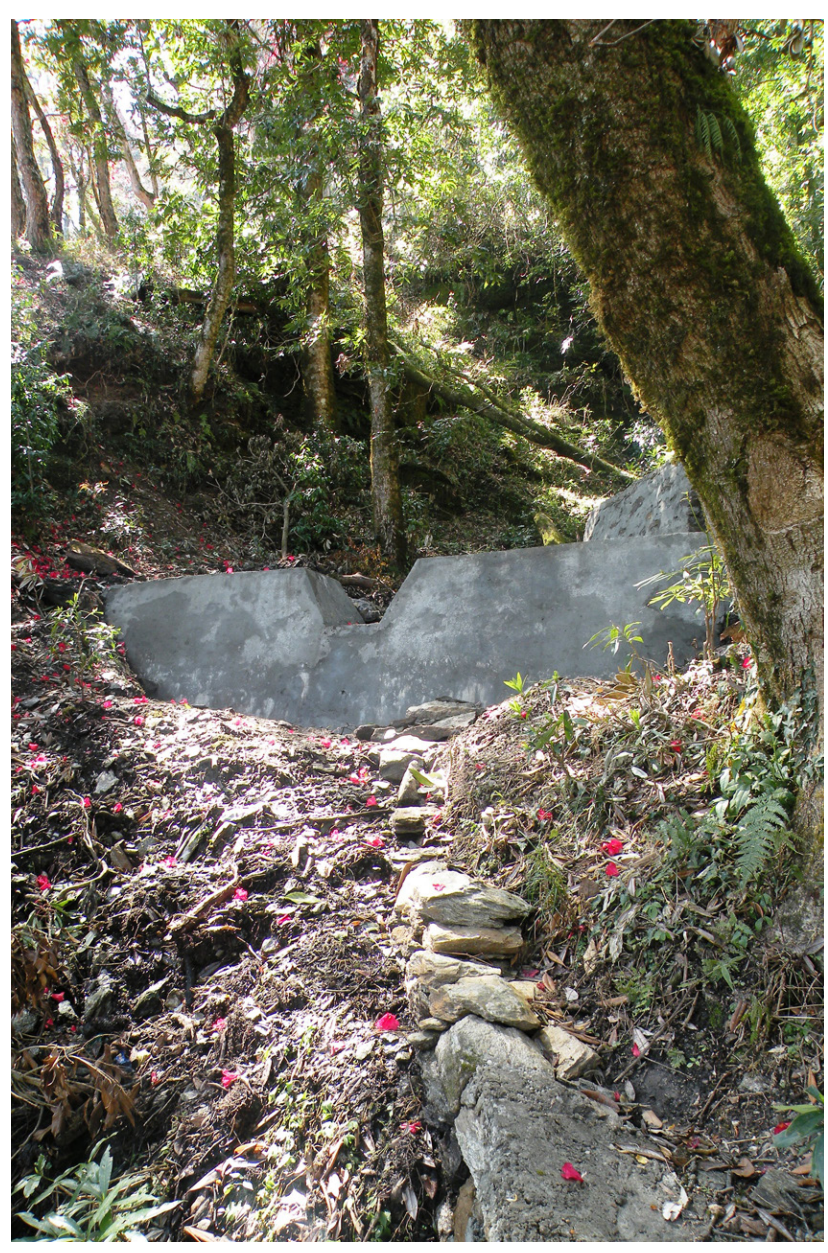

Fig. 8. Debris dam to check gully erosion in forest land 
any casualty and above all the whole area along with agriculture land bulging towards toe were evidences of landslides. The hazard of landslides manifestated in unit 3D (Dhanauli village), 4C (Sandani village), 4D (Bari, Jaduri and Thala villages), 5D (Rest part of Jaduri village). It's noteworthy that unit 4D was at the worst stage (Table 4, Fig. 6). Landslides occurred in whole Bari village. The upper part (about $50 \%$ of area) has terraces collapsing, gully development, debris accumulation, disappearance of natural spring while the lower half present discontinuity in terraces and bulging of the fields. The landslides area was supported by regular check dams, about $30 \mathrm{~m}$ of length each. These check dams were constructed along Jalia Gad at the toe of Bari village (Fig. 8). In Jaduri village present landslide was the part of old landslide. The resettlement processes occurred upon the old landslide part and the agricultural processes were started by the inhabitants but again landslide triggered about thirty five years back. After this hazard some part was left barren on account of unalterably degraded lands which use to collapse in every rainy season and some part was cultivated to fulfill their livelihood. Out of the cultivated area some part was again left barren due to the frequent collapsing of terraces due to landslide movement (Fig. 9). In whole Thala village (settlement and cultivated land) is under the grip of landsliding. The discontinuity of agricultural terraces due to landslide has created three gullies within the cultivated land. Consequently the entire cultivated land was divided into three major agricultural zones (Fig. 10). These gullies provide intensive erosion to the area. These were about 1.5 to $2.0 \mathrm{~m}$ deep and 1.5 to $2.0 \mathrm{~m}$ wide so the collapsing of agricultural terraces in each rainy season has become a common problem as the sufficient rain water accumulates in these gullies. The cultivated land destroyed along these gullies is about 101000 $\mathrm{m}^{2}$. After rain repairable part of terraces is reconstructed each year to fulfill their food requirements from the agricultural field.

Soil creeping was observed only in one unit, i.e. 5D. A zone covering about $10,379 \mathrm{~m}^{2}$ area exists in the Dense Mixed forest. The tilting of huge trees in this particular zone indicates the instability of the forest area where anthropogenic process was negligible and dense mixed vegetation cover seemed to be good protective cover (Fig. 11).

Table 4. Characteristics of landslide hazard sites in the Ghuniyoli Watershed

\begin{tabular}{|c|c|c|c|c|c|}
\hline $\begin{array}{l}\text { Locality } \\
\text { (basic } \\
\text { unit) }\end{array}$ & $\begin{array}{l}\text { Altitude } \\
\text { [m a.s.1.] }\end{array}$ & $\begin{array}{c}\text { Geographical } \\
\text { coordinates }\end{array}$ & Observed evidences & Causative factors & $\begin{array}{l}\text { Area affect- } \\
\text { ed by land } \\
\text { subsidence } \\
\text { hazard }\left[\mathrm{m}^{2}\right]\end{array}$ \\
\hline $\begin{array}{l}\text { Dhanauli } \\
\text { (3D) } \\
\text { Fig. } 10\end{array}$ & 1,550 & $\begin{array}{l}29^{0} 40^{\prime} 23 ” \mathrm{~N} \\
79^{\circ} 52^{\prime} 07^{\prime \prime} \mathrm{E}\end{array}$ & $\begin{array}{l}\text { Cracks in houses ( } 3 \text { cases observed) } \\
\text { Subsidence of courtyard } \\
\text { Subsidence of house stairs } \\
\text { iv. Subsidence of agriculture land. }\end{array}$ & $\begin{array}{l}\text { i. Existence of sea- } \\
\text { sonal rivulet at the } \\
\text { toe of the affected } \\
\text { area. }\end{array}$ & 1,050 \\
\hline $\begin{array}{l}\text { Sandani } \\
(4 C)\end{array}$ & 1,500 & $\begin{array}{l}29^{0} 40^{\prime} 18^{\prime \prime} \mathrm{N} \\
79^{0} 51 ' 31^{\prime \prime} \mathrm{E}\end{array}$ & $\begin{array}{l}\text { Damaged agricultural terraces } \\
\text { Fissures in the houses } \\
\text { iii. Collapsing of courtyard }\end{array}$ & $\begin{array}{l}\text { Existence of Ghuni- } \\
\text { yoli Gad at the toe of } \\
\text { the village } \\
\text { ii. Land subsidence } \\
\text { was taking place } \\
\text { along Ghuniyoli Gad } \\
\text { and gradually affect- } \\
\text { ing towards the up- } \\
\text { per reaches. }\end{array}$ & 337,500 \\
\hline $\begin{array}{l}\text { Bari } \\
(4 D) \\
\text { Fig. } 11\end{array}$ & 1,400 & $\begin{array}{l}29^{0} 40^{\prime} 22^{\prime \prime} \mathrm{N} \\
79^{\circ} 51^{\prime} 53^{\prime \prime} \mathrm{E}\end{array}$ & $\begin{array}{l}\text { Discontinuity of agricultural terrace wall and } \\
\text { their bulging towards toe } \\
\text { ii. Tilting of trees along the crown of affected } \\
\text { area. } \\
\text { Destruction of trees/plants and consequent } \\
\text { creation of gully } \\
\text { This gully development caused collapsing of } \\
\text { the terraces. } \\
\text { The original source of water spring was buried } \\
\text { under the debris produced by terrace collaps- } \\
\text { ing and this spring was reappeared in } 20 \mathrm{~m} \text { be- } \\
\text { low from its original place. } \\
\text { vi. Construction of regular check dams (30 } \\
\text { m length) by Soil Conservation Department } \\
\text { along Jalia Gad (tributary of Ghuniyoli Gad) at } \\
\text { the toe of Bari village }\end{array}$ & $\begin{array}{l}\text { Severe toe erosion } \\
\text { by Jalia Gad } \\
\text { ii. Agricultural pro- } \\
\text { cesses at the crown } \\
\text { of the area along } \\
\text { vegetation less } \\
\text { slope. }\end{array}$ & 16,800 \\
\hline
\end{tabular}


Table 4 cont.

\begin{tabular}{|c|c|c|c|c|c|}
\hline $\begin{array}{l}\text { Locality } \\
\text { (basic } \\
\text { unit) }\end{array}$ & $\begin{array}{l}\text { Altitude } \\
{[\mathrm{m} \text { a.s.1.] }}\end{array}$ & $\begin{array}{l}\text { Geographical } \\
\text { coordinates }\end{array}$ & Observed evidences & Causative factors & $\begin{array}{c}\text { Area affect- } \\
\text { ed by land } \\
\text { subsidence } \\
\text { hazard }\left[\mathrm{m}^{2}\right]\end{array}$ \\
\hline $\begin{array}{l}\text { Jaduri } \\
\text { (4D) } \\
\text { Fig. } 9\end{array}$ & 1,700 & $\begin{array}{l}29^{0} 39^{\prime} 47^{\prime \prime} \mathrm{N} \\
79^{0} 51^{\prime} 41^{\prime \prime} \mathrm{E}\end{array}$ & $\begin{array}{l}\text { a) the houses got cracks during land subsid- } \\
\text { ence. } \\
\text { ii. Collapsed agricultural fields and dislocated } \\
\text { as evident from their discontinuity } \\
\text { Whenever the terraces were reconstructed af- } \\
\text { ter land subsidence, the subsided soil forms } \\
\text { steeply sloping terraces which were again vul- } \\
\text { nerable to erosion } \\
\text { iv. Check dams were constructed at the toe of } \\
\text { the agricultural land along Jalia Gad as well as } \\
\text { amid agricultural terraces but these terraces } \\
\text { were not remained stable due to the occasional } \\
\text { occurrence of land subsidence. } \\
\text { The broken and tilted check dams amid the ag- } \\
\text { ricultural land and dislocated check dams along } \\
\text { Jalia bank speak of the still active process of } \\
\text { land subsidence. } \\
\text { b) this area possessed systematic agricultural } \\
\text { processes but the subsided land became irre- } \\
\text { versible consequently the whole area was con- } \\
\text { verted into barren land. } \\
\text { Ii. Due to instability agricultural field were } \\
\text { converted into steeply sloping land and the } \\
\text { terraces use to collapse again during monsoons } \\
\text { whenever the terraces were reconstructed } \\
\text { along this sloping land. }\end{array}$ & $\begin{array}{l}\text { Severe toe erosion } \\
\text { by Jalia Gad } \\
\text { ii. Outwardly slop- } \\
\text { ing agricultural ter- } \\
\text { races along the hill }\end{array}$ & 4,000 \\
\hline $\begin{array}{l}\text { Thala } \\
\text { (4D) }\end{array}$ & 1,750 & $\begin{array}{l}29^{0} 39^{\prime} 49^{\prime \prime} \mathrm{N} \\
79^{0} 52^{\prime} 04^{\prime \prime} \mathrm{E}\end{array}$ & $\begin{array}{l}\text { The tilting of agricultural terraces and bulging } \\
\text { towards toe. } \\
\text { ii. The houses got cracked (five cases) and sub- } \\
\text { sided vertically. These houses were ultimate- } \\
\text { ly dismantled by the inhabitants for escaping } \\
\text { from any casualty and the land is being used for } \\
\text { agricultural purposes at present. } \\
\text { iii. The cracks visible on village path (about } 6 \\
\text { to } 7 \text { m) and sliding of the land along this crack. } \\
\text { This crack is usually filled by the inhabitants } \\
\text { to save village path, but during monsoons this } \\
\text { fissure reappears. }\end{array}$ & $\begin{array}{l}\text { Severe toe erosion } \\
\text { along Jalia Gad } \\
\text { ii. Unscientific an- } \\
\text { thropogenic inter- } \\
\text { ferences }\end{array}$ & $\begin{array}{l}\text { Total } \\
\text { village was } \\
\text { subsiding } \\
\text { downward }\end{array}$ \\
\hline $\begin{array}{l}\text { Rest Part } \\
\text { of Jaduri } \\
(5 \mathrm{D})\end{array}$ & 1,700 & $\begin{array}{l}29^{0} 39^{\prime} 47^{\prime \prime} \mathrm{N} \\
79^{0} 51^{\prime} 41^{\prime \prime} \mathrm{E}\end{array}$ & $\begin{array}{l}\text { Tilting of agricultural terraces } \\
\text { ii. Cracks in house. }\end{array}$ & $\begin{array}{l}\text { i. Severe toe erosion } \\
\text { along Jalia Gad }\end{array}$ & 3,000 \\
\hline $\begin{array}{l}\text { Dankhali } \\
(5 \mathrm{D})\end{array}$ & 1,900 & $\begin{array}{l}\text { 29039'33”N } \\
79^{\circ} 52^{\prime} 09^{\prime \prime} \mathrm{E}\end{array}$ & $\begin{array}{l}\text { i. Collapsing of agricultural Terraces along out- } \\
\text { wardly sloping land during monsoon period }\end{array}$ & $\begin{array}{l}\text { i. Existence of Pine } \\
\text { Forest (with shal- } \\
\text { low soil cover) along } \\
\text { steeply sloping land } \\
\text { proved major factor } \\
\text { for degradation. }\end{array}$ & 2,500 \\
\hline
\end{tabular}

\section{Anthropogenic hazards}

Stone quarry was observed in unit 4D and 5D. In unit $4 \mathrm{D}$, two stone quarry were observed, which disturbed the stability of the landform, thus head ward erosion took place and the quarry generated debris was accumulated along footpath. In unit 5D, two stone quar- ry were observed in the flat land which created huge depression, thus ultimately leading to intensive gully erosion during rains.

Man induced terrace collapsing occurred in 3 units while 5 units experienced both type (flood induced and man induced) of terrace collapsing (Table 3, Fig. 6). 

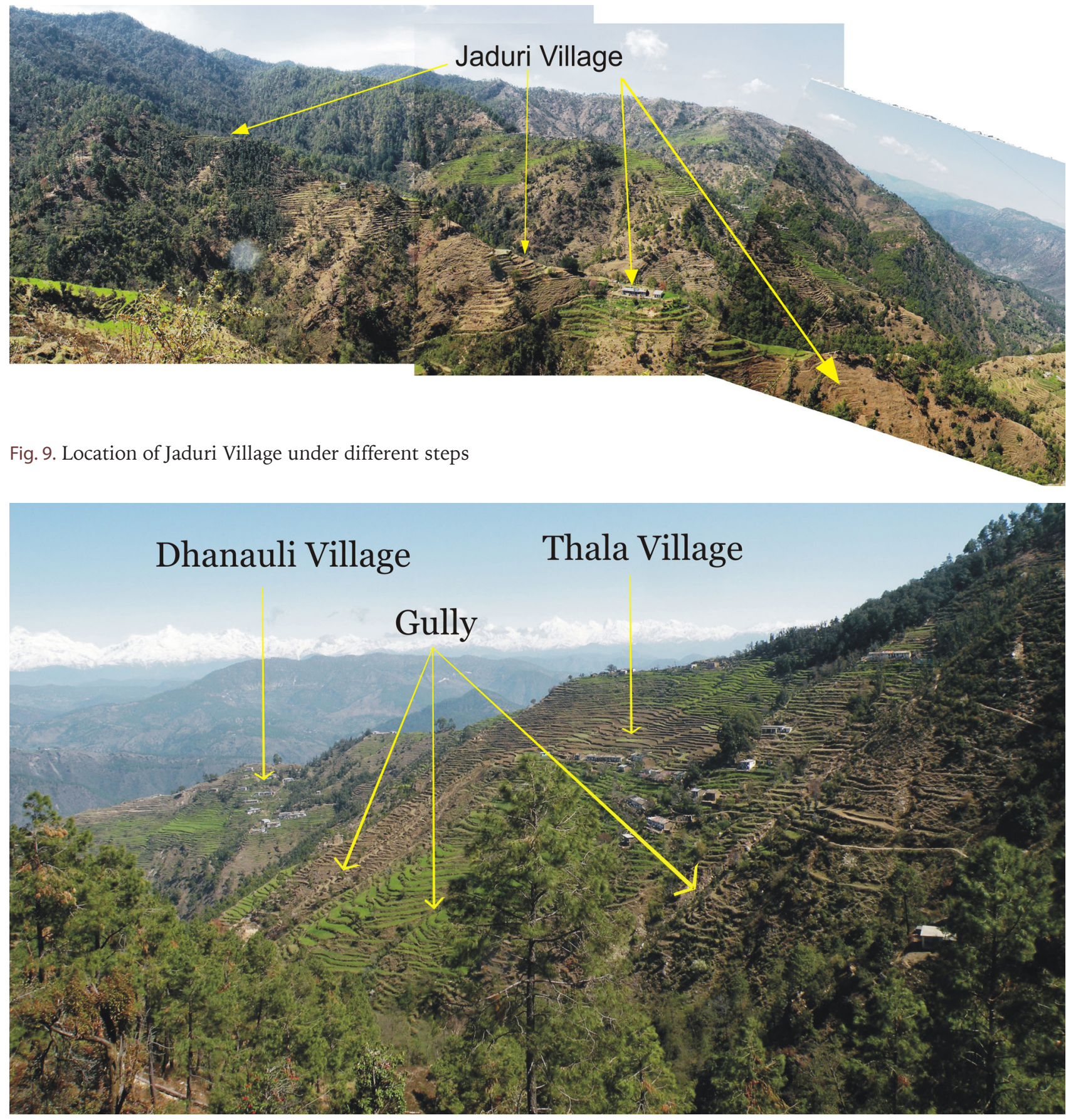

Fig. 10. Location of Thala and Dhanauli village. Gully development within cultivated land in Thala Village

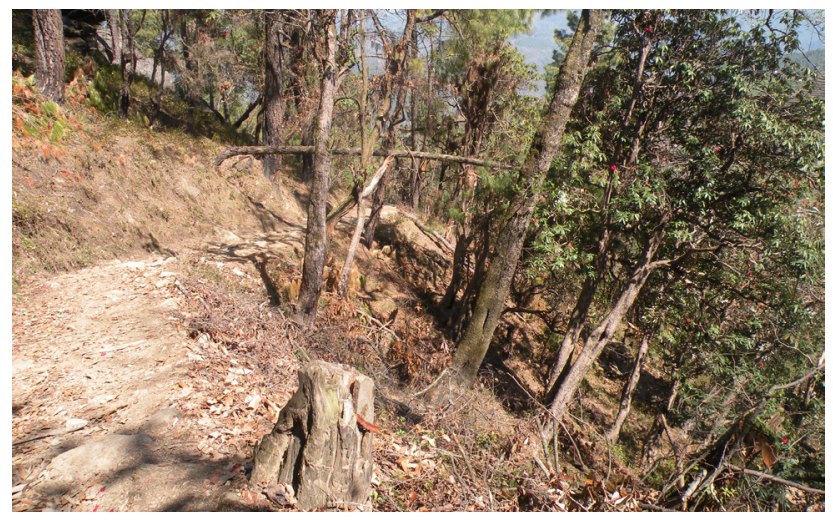

Fig. 11. Tilted trees due to soil creeping 


\section{Extent of geomorphic hazards}

Figure 12 illustrates that surficial erosion (se) covers maximum area under 14 units. Unit 3B is the most hazardous $(92.08 \%)$ where surficial erosion covers $87.27 \%$ area while debris flows also contributes considerably (4.36\% area) (Table 5). 4C and 4D units contributes significantly where $73 \%$ and $71 \%$ area is hazardous and surficial erosion covers $68 \%$ and $47 \%$ area respectively. Landslides cover about $4 \%$ and $23 \%$ area of the units respectively. Excluding surficial erosion, the most hazardous unit is $4 \mathrm{D}$ where $24 \%$ area is hazardous and dominating hazardous process (23\%) is landsliding (Table 5).

Figures $13 \mathrm{~A}$ and $13 \mathrm{~B}$ exhibit that surficial erosion covers maximum area under the watershed, i.e. $32.29 \%$ (Table 6). If surficial erosion is excluded, landsliding (2.64\%) covers maximum hazardous area out of total watershed area. Under the assessment of geomorphic hazards in studied units, it is observed that unit 4C (7.15\%) followed by unit 4D (6.95\%), $3 \mathrm{~B}(6.21 \%)$ and 4B (5.28\%) cover maximum hazardous area out of total hazardous area of the watershed, i.e. $36.55 \%$. While excluding surficial erosion maximum hazardous unit is $4 \mathrm{D}$, covering $2.38 \%$ area out of $4.26 \%$ hazardous area of the watershed excluding surficial erosion (Table 6).

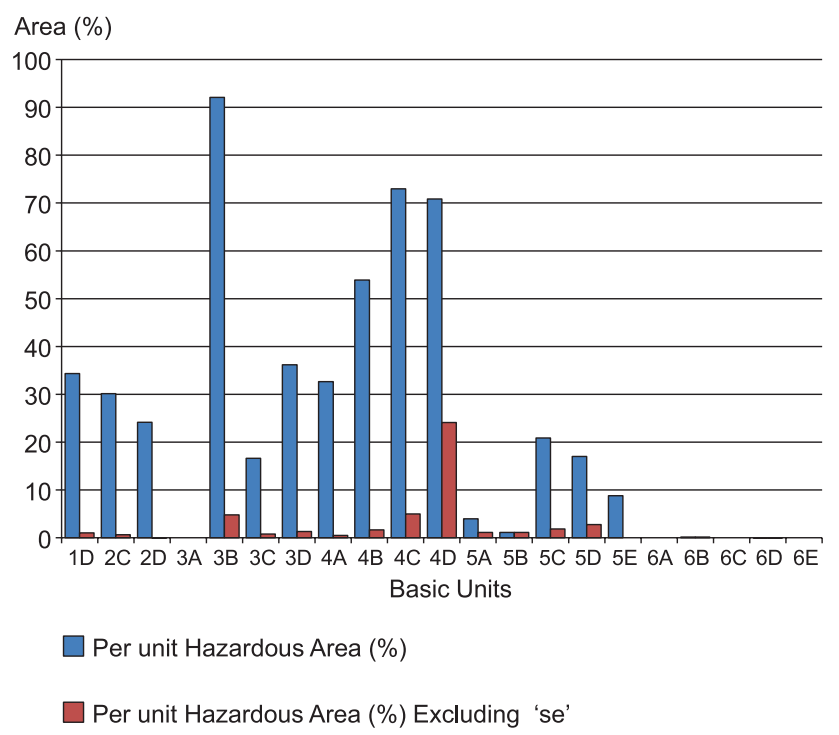

Fig. 12. Area under different hazardous geomorphic processes in particular units

Figures $14 \mathrm{~A}$ and $14 \mathrm{~B}$ exhibit that out of total hazardous area of the watershed, surficial erosion covers maximum area i.e. $88.58 \%$. If surficial erosion is excluded, landsliding (63.24\%) covers the most hazardous area (Table 7 ).

Table 5. Ghuniyoli Watershed: Area in percent out of per unit area under different hazardous geomorphic processes

\begin{tabular}{|c|c|c|c|c|c|c|c|c|c|c|c|c|c|}
\hline \multirow{2}{*}{$\begin{array}{l}\text { Basic } \\
\text { units }\end{array}$} & \multicolumn{11}{|c|}{ Hazard Type } & \multirow{2}{*}{$\begin{array}{c}\text { Per unit } \\
\text { hazardous area }\end{array}$} & \multirow{2}{*}{$\begin{array}{l}\text { Per unit } \\
\text { hazardous area } \\
\text { excluding "se" } \\
\text { 0] }\end{array}$} \\
\hline & se & go & gn & gc & fc & aw & $\mathrm{df}$ & ls & sc & sq & $\mathrm{mc}$ & & \\
\hline $1 \mathrm{D}$ & 33.330 & - & - & - & 1.020 & - & - & - & - & - & - & 34.350 & 1.020 \\
\hline $2 \mathrm{C}$ & 29.470 & 0.150 & 0.510 & - & - & - & - & - & - & - & - & 30.130 & 0.660 \\
\hline $2 \mathrm{D}$ & 24.170 & - & - & - & 0.010 & - & - & - & - & - & - & 24.180 & 0.010 \\
\hline $3 \mathrm{~A}$ & - & - & - & - & - & - & - & - & - & - & - & N.A. & N.A. \\
\hline $3 B$ & 87.270 & 0.360 & 0.080 & - & 0.003 & - & 4.360 & - & - & - & 0.005 & 92.080 & 4.810 \\
\hline $3 \mathrm{C}$ & 15.870 & 0.520 & 0.250 & - & 0.003 & - & - & - & - & - & 0.001 & 16.650 & 0.780 \\
\hline $3 \mathrm{D}$ & 34.850 & 0.370 & 0.150 & 0.660 & - & - & - & 0.170 & - & - & - & 36.200 & 1.350 \\
\hline $4 \mathrm{~A}$ & 32.170 & 0.360 & 0.140 & - & - & - & - & - & - & - & - & 32.670 & 0.500 \\
\hline $4 B$ & 52.250 & 1.440 & 0.220 & - & 0.002 & - & - & - & - & - & - & 53.910 & 1.660 \\
\hline $4 \mathrm{C}$ & 68.000 & 1.110 & 0.130 & - & - & - & - & 3.750 & - & - & 0.004 & 72.990 & 4.990 \\
\hline $4 \mathrm{D}$ & 46.750 & 0.690 & 0.080 & 0.180 & 0.003 & 0.300 & 0.003 & 22.850 & - & 0.006 & - & 70.860 & 24.110 \\
\hline $5 \mathrm{~A}$ & 02.860 & 1.140 & - & - & - & - & - & - & - & - & - & 04.000 & 1.140 \\
\hline $5 B$ & - & 1.140 & - & - & - & - & - & - & - & - & - & 01.140 & 1.140 \\
\hline $5 \mathrm{C}$ & 19.000 & 0.890 & - & 0.990 & 0.004 & - & - & 0.210 & - & - & - & 20.880 & 1.880 \\
\hline $5 \mathrm{D}$ & 14.250 & 1.230 & 0.050 & 0.250 & - & - & - & - & 1.040 & 0.003 & - & 17.030 & 2.780 \\
\hline $5 \mathrm{E}$ & 08.820 & - & - & - & - & - & - & - & - & - & - & 8.820 & N.A. \\
\hline $6 \mathrm{~A}$ & - & - & - & - & - & - & - & - & - & - & - & N.A. & N.A. \\
\hline $6 \mathrm{~B}$ & - & 0.190 & - & - & - & - & - & - & - & - & - & 0.190 & 0.190 \\
\hline $6 \mathrm{C}$ & - & - & - & - & - & - & - & - & - & - & - & N.A. & N.A. \\
\hline $6 \mathrm{D}$ & - & 0.010 & - & - & - & - & - & - & - & - & - & 0.010 & 0.010 \\
\hline $6 \mathrm{E}$ & - & - & - & - & - & - & - & - & - & - & - & N.A. & N.A. \\
\hline
\end{tabular}

Type: explanations of abbreviations see Fig. 6; N.A. - not available. 
Table 6. Ghuniyoli Watershed: Area in percent out of total watershed area under different hazardous geomorphic processes

\begin{tabular}{|c|c|c|c|c|c|c|c|c|c|c|c|c|c|}
\hline \multirow{2}{*}{$\begin{array}{l}\text { Basic } \\
\text { units }\end{array}$} & \multicolumn{11}{|c|}{ Hazard Type } & \multirow{2}{*}{$\begin{array}{c}\text { Total } \\
\text { hazardous } \\
\text { area } \\
{[\%]}\end{array}$} & \multirow{2}{*}{$\begin{array}{c}\text { Total } \\
\text { hazardous area } \\
\text { excluding "se" }\end{array}$} \\
\hline & se & go & gn & gc & fc & aw & $\mathrm{df}$ & Ls & SC & $\mathrm{sq}$ & $\mathrm{mc}$ & & \\
\hline $1 \mathrm{D}$ & 0.050 & - & - & - & 0.003 & - & - & - & - & - & - & 0.053 & 0.003 \\
\hline $2 \mathrm{C}$ & 1.370 & 0.007 & 0.024 & - & - & - & - & - & - & - & - & 1.401 & 0.031 \\
\hline $2 \mathrm{D}$ & 0.710 & - & - & - & 0.004 & - & - & - & - & - & - & 0.714 & 0.004 \\
\hline $3 \mathrm{~A}$ & - & - & - & - & - & - & - & - & - & - & - & N.A. & N.A. \\
\hline $3 \mathrm{~B}$ & 5.870 & 0.024 & 0.005 & - & 0.003 & - & 0.300 & - & - & - & 0.004 & 6.206 & 0.336 \\
\hline $3 \mathrm{C}$ & 1.540 & 0.051 & 0.024 & - & 0.004 & - & - & - & - & - & 0.002 & 1.621 & 0.081 \\
\hline $3 \mathrm{D}$ & 2.050 & 0.022 & 0.009 & 0.041 & - & - & - & 0.010 & - & - & - & 2.132 & 0.082 \\
\hline $4 \mathrm{~A}$ & 0.900 & 0.010 & 0.004 & - & - & - & - & - & - & - & - & 0.914 & 0.014 \\
\hline $4 B$ & 5.110 & 0.142 & 0.022 & - & 0.003 & - & - & - & - & - & 0.002 & 5.279 & 0.169 \\
\hline $4 \mathrm{C}$ & 6.650 & 0.110 & 0.013 & - & - & - & - & 0.370 & - & - & 0.004 & 7.147 & 0.497 \\
\hline $4 \mathrm{D}$ & 4.570 & 0.068 & 0.008 & 0.023 & 0.004 & 0.030 & 0.001 & 2.240 & - & 0.007 & - & 6.951 & 2.381 \\
\hline $5 \mathrm{~A}$ & 0.140 & 0.059 & - & - & - & - & - & - & - & - & - & 0.199 & 0.059 \\
\hline $5 B$ & - & 0.112 & - & - & - & - & - & - & - & - & - & 0.112 & 0.112 \\
\hline $5 \mathrm{C}$ & 1.860 & 0.087 & - & 0.107 & 0.005 & - & - & 0.020 & - & - & - & 2.079 & 0.219 \\
\hline $5 \mathrm{D}$ & 1.400 & 0.121 & 0.006 & 0.024 & - & & - & - & 0.110 & 0.004 & - & 1.665 & 0.265 \\
\hline $5 E$ & 0.070 & - & - & - & - & - & - & - & - & - & - & 0.070 & N.A. \\
\hline $6 \mathrm{~A}$ & - & - & - & - & - & - & - & - & - & - & - & N.A. & N.A. \\
\hline $6 \mathrm{~B}$ & - & 0.001 & - & - & - & - & - & - & - & - & - & 0.001 & 0.001 \\
\hline $6 \mathrm{C}$ & - & - & - & - & - & - & - & - & - & - & - & N.A. & N.A. \\
\hline $6 \mathrm{D}$ & - & 0.002 & - & - & - & - & - & - & - & - & - & 0.002 & 0.002 \\
\hline $6 \mathrm{E}$ & - & - & - & - & - & - & - & - & - & - & - & N.A. & N.A. \\
\hline $\begin{array}{l}\text { Total } \\
\text { Area }\end{array}$ & 32.290 & 0.816 & 0.115 & 0.195 & 0.026 & 0.030 & 0.301 & 2.640 & 0.110 & 0.011 & 0.012 & 36.546 & 4.256 \\
\hline
\end{tabular}

N.A. - not available.
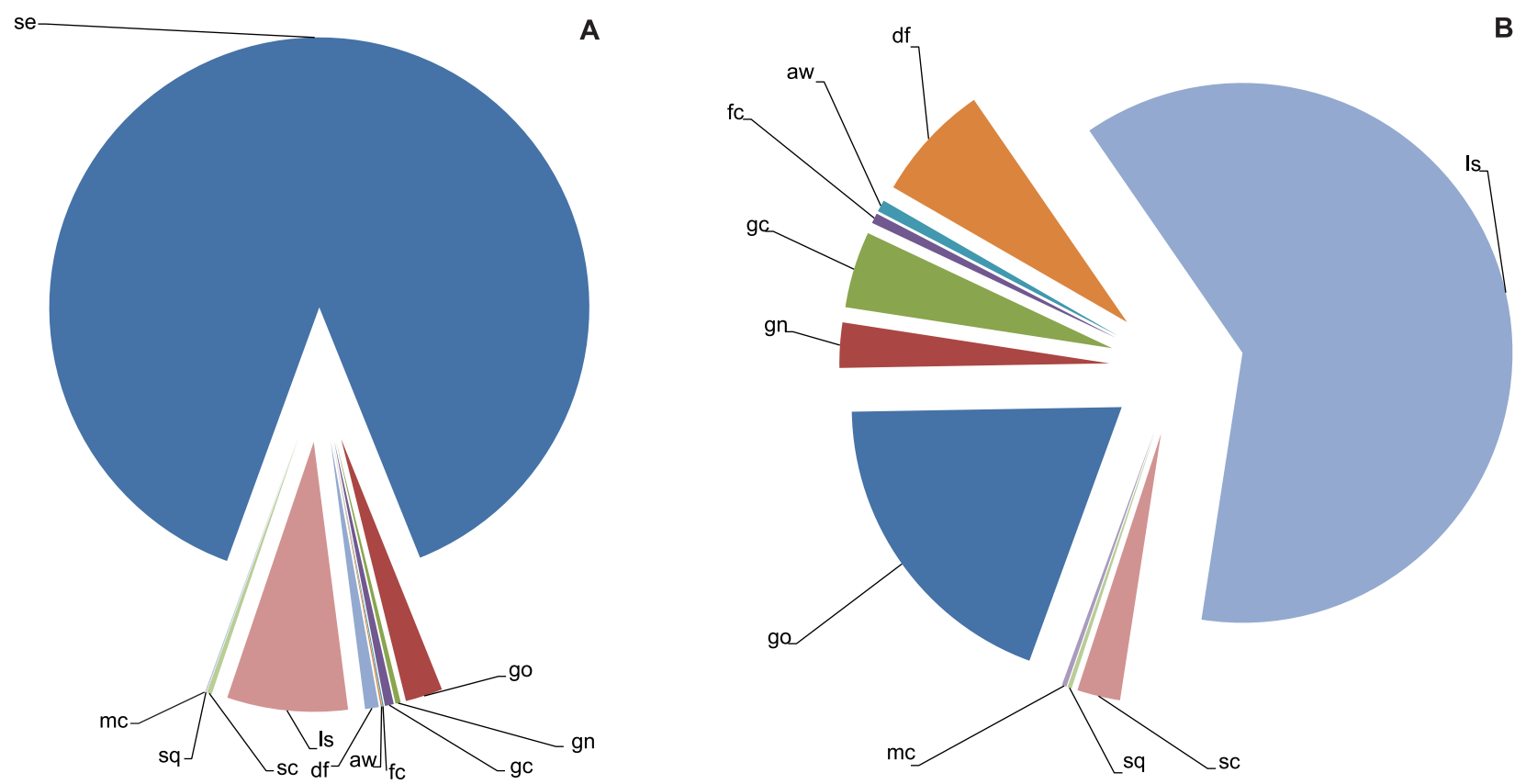

Fig. 13. Area under different hazardous geomorphic processes out of total watershed area A - excluding "se", B - including "se". Explanations of geomorphic hazards abbreviations see Fig. 6 

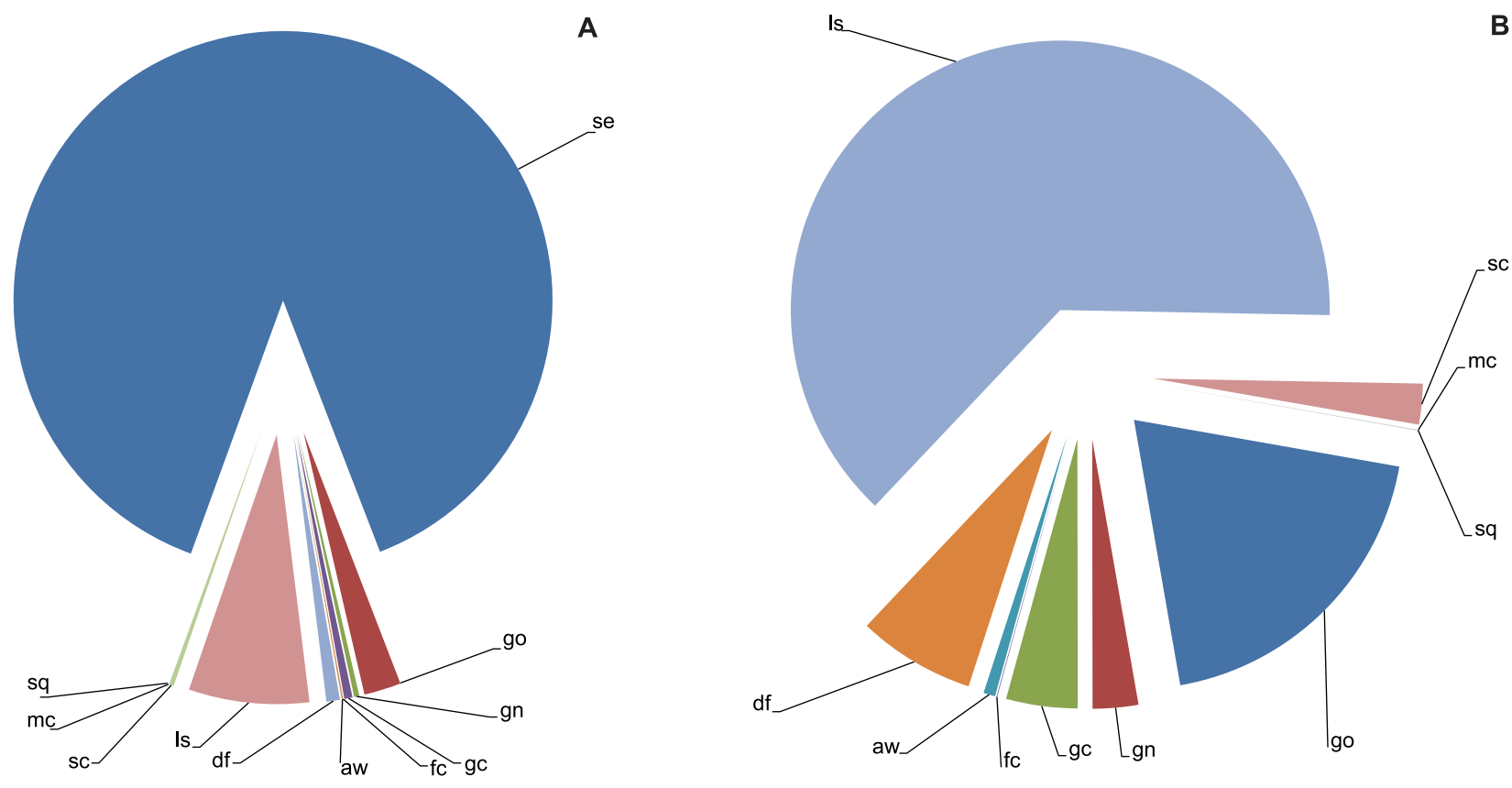

Fig. 14. Area under different hazardous geomorphic processes out of total hazardous area of watershed A - excluding "se", B - including "se". Explanations of geomorphic hazards abbreviations see Fig. 6

Table 7. Ghuniyoli Watershed: Hazardous area out of total hazardous area

\begin{tabular}{lcc}
\hline Hazard type & $\begin{array}{c}\text { Hazardous area } \\
\text { excluding "se" }\end{array}$ & $\begin{array}{c}\text { Hazardous area } \\
\text { including "se" }\end{array}$ \\
\cline { 2 - 3 } se & \multicolumn{3}{c}{$\left[\begin{array}{c} \\
\text { go }\end{array}\right.$} & - & 88.583 \\
gn & 19.470 & 2.222 \\
gc & 2.730 & 0.312 \\
fc & 4.280 & 0.489 \\
aw & 0.040 & 0.005 \\
df & 0.700 & 0.080 \\
ls & 7.050 & 0.805 \\
sc & 63.250 & 7.222 \\
mc & 2.440 & 0.278 \\
sq & 0.020 & 0.002 \\
Total & 0.020 & 0.002 \\
\hline
\end{tabular}

The Ghuniyoli Gad watershed encompasses 36\% hazardous area while $4 \%$ hazardous area excluding surficial erosion out of the $10.22 \mathrm{~km}^{2}$ area of the watershed.

\section{Assessment of potential geomorphic hazards}

The watershed was classified using four degrees for inferred instability (Fig. 15). There are $4.76 \%$ basic units where more than $50 \%$ of the affected area is suspected to be endangered (degree 4). There are $19.04 \%$ basic units where $25 \%$ to $50 \%$ of affected area is suspected to be endangered (degree 3 ). There are $38.10 \%$ basic units

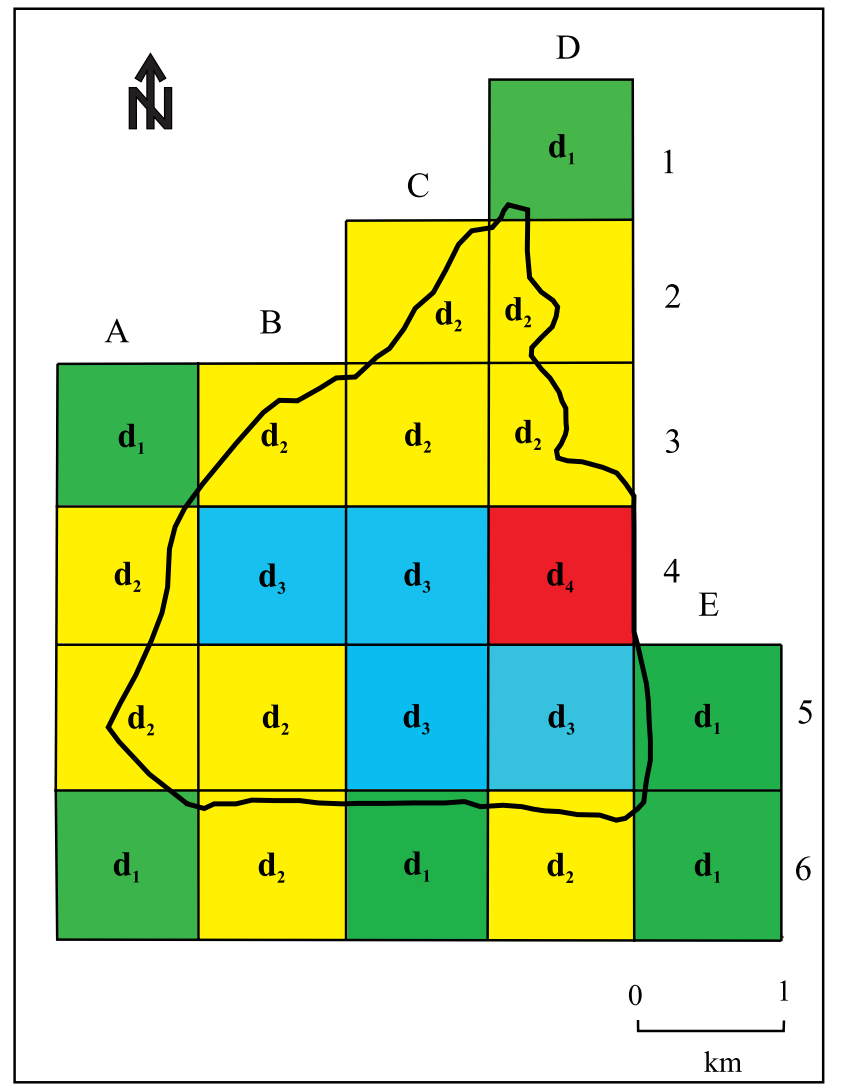

Fig. 15. Types and corresponding degree of suspected instability. $d_{1}$ - in case of future mismanaged land use the instability is suspected, $d_{2}$ - up to $25 \%$ of affected area is suspected to be unstable, $\mathrm{d}_{3}-25 \%$ to $50 \%$ of affected area is suspected to be unstable, $\mathrm{d}_{4}-$ more than $50 \%$ of affected area is suspected to be unstable 


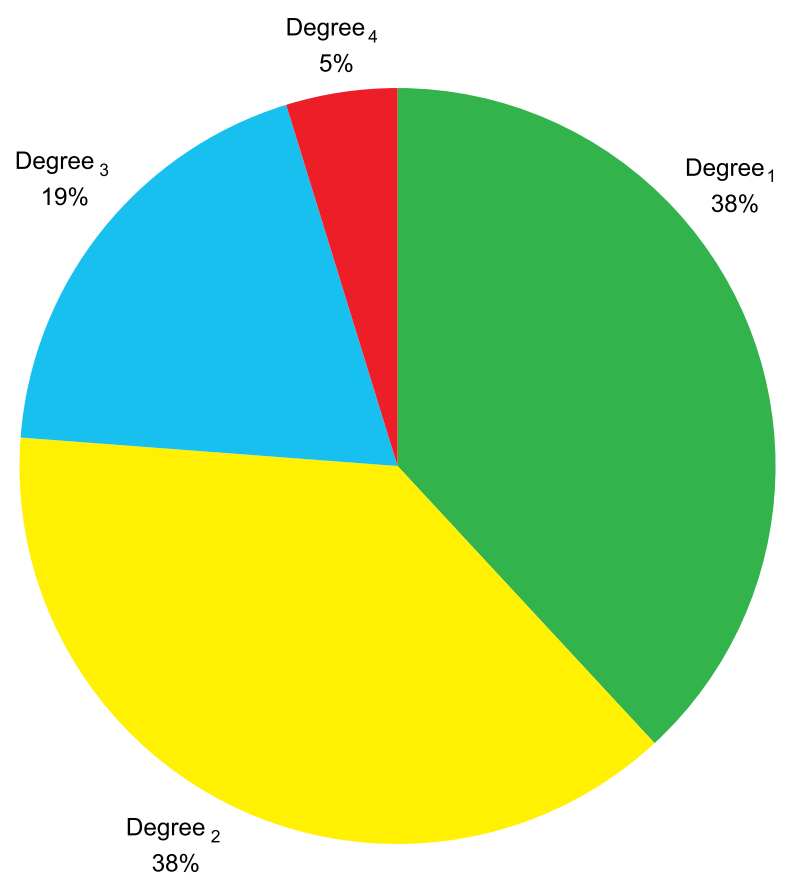

Fig. 16. Assessment of potential geomorphic hazards: percent of units under different corresponding degrees of suspected instability. Explanations of degrees of instability see Fig. 15

where less than $25 \%$ of the affected area has potential for future damage (degree 2 ) and $38.1 \%$ basic units where degree of instability (degree 1) is suspected to be high in case of future mismanaged land use. Maximum basic units were in favour of degree 1 and degree 2 categories while minimum basic units were in favour of degree 4 category (Fig. 16). So deprivation of watershed is under the control of recovery and there exists possibilities to improve the degraded environment by mitigating the hazardous processes in watershed.

\section{Conclusion}

The study results showed that majority of land-degradation problems or slope instability processes of the watershed are occurring along slopes under anthropogenic activities, especially agricultural and settlement processes as well as deforestation. Terraced agriculture especially outwardly sloping agricultural terraces are found basically vulnerable for slope instability. Apart from the outwardly sloping agricultural terraces, degraded Pine (Pinus roxburghii) forest cover also contributed in the formation of highly active gullies (during monsoon period) which ultimately leads to slope instability process. The assessment of slope instability bring up that the anthropogenic interferences boosted to the vulnerability of the watershed and completely altered the physical landscape on one hand and the cultural scenario on the other.
Land is the basic resource for the livelihood of the inhabitants and agriculture is still the mainstay of the entire population so preventive measures are required by the government to protect the sloping terraces. This land conservation can only strengthen the economy of the inhabitants and diminish the geomorphic vulnerability of the watershed.

\section{Acknowledgements}

I would like to express my thanks to prof. Zofia Raczkowska for her extremely important help in the process of improving my paper. I owe my thanks to the two anonymous reviewers.

\section{References}

Alexander D. E., 2008. A brief survey of GIS in mass-movement studies, with reflections on theory and methods. Geomorphology 94: 261-267.

Barnard P. L., Owen L.A., Sharma M.C., Finkel R.C., 2001. Natural and human-induced landsliding in the Garhwal Himalaya of northern India. Geomorphology 40: 21- 35.

Bartarya S.K., Valdiya K.S., 1989. Landslides and erosion in the catchment of Gaula River, Kumaun Lesser Himalaya, India. Mountain Research and Development 9(2): $405-419$.

Bhandari R.K., 1988. Eco-development in the Garhwal Himalaya with particular reference to field study and monitoring of landslides and development of innovative control measures. Report D.O.En.: 1-150.

Bhandari R.K., Gupta C., 1985. Problems of landslides in the Himalaya and future directions. In: Singh, J.S. (ed.), Environmental Regeneration in Himalaya, Concepts and Strategies. Gyanodaya Parkashan, Nainital: 39-57.

Byers A., 1985. A geomorphic study of man-induced soil-erosion Sagarmatha (MT. Everest) National Park, Khumbu Nepal. Mountain Research and Development 6(1): 83-87.

Chandel V.B.S., Brar K.K., 2010. Climatic extreme and changing climate in western Himalayas: A study of cloudburst incidences in Himachal Pradesh. Punjab Geographer 6: 29-40.

Chandel V.B.S., Brar K.K., Chauhan Y., 2011. RS \& GIS based landslide hazard zonation of mountainous terrains: A study from middle Himalayan Kullu district, Himachal Pradesh, India. International Journal of Geomatics and Geosciences 2(1): 121-132.

Chen H., Lee C.F., 2003. A dynamic model for rainfall-induced landslides on natural slopes. Geomorphology 51: 269-288.

Cole V., Sinclair A.J., 2002. Measuring the ecological footprint of a Himalayan tourist centre. Mountain Research and Development 22(2): 132-141.

Eriksson M., 2006. Climate change and its implication for human health in the Himalaya. Sustainable mountain development in the Greater Himalayan region. ICIMOD Summer News Letter No. 50: 11-13.

Fourniadis I.G., Liu J.G., Mason P.J., 2007. Landslide hazard assessment in the Three Gorges area, China, uses ASTER imagery: Wushan-Badong. Geomorphology 84: 126-144.

Gardner J.S., Dekens J., 2007. Mountain hazards and the resilience of social-ecological systems: lessons learned in India and Canada. Natural Hazards 41: 317-336.

Gardner J.S., Saczuk E., 2004. Systems for hazards identification in high mountain areas: an example from the Kullu District, Western Himalaya. Journal of Mountain Science 1: 115-127.

Haigh M.J., Rawat J.S., Rawat M.S., Baratrya S.K., Rai S.P., 1995. Interactions between forest and landslide activity along new 
highways in the Kumaun Himalaya. Forest Ecology and Management 78: 173-189.

IPCC, 2001. Climate Change 2001: The Scientific Basis. Contribution of Working Group I to the Third Assessment Report of the Intergovernmental Panel on Climate Change [Houghton, J.T.,Y. Ding, D.J. Griggs, M. Noguer, P.J. van der Linden, X. Dai, K. Maskell, and C.A. Johnson (eds.)].Cambridge University Press, Cambridge, United Kingdom and New York, NY, USA, 881.

Keefer D. K., 1994. The importance of earthquake induced landslides to long term slope erosion and slope failure hazards in seismically active regions. Geomorphology 10: 265-284.

Keefer D. K., 2002. Investigating landslides caused by earthquakes: A historical review. Surveys in Geophysics 23: 473-510.

Kienholz H., Hafner H., Schneider G., Tamarkar R., 1983. Mountain hazards in Napal's Middle Mountains with map of land use and geomorphic damages (Kathmandu- Kakani area). Mountain Research and Development 3(3): 195-220.

Kienholz H., SchneIder G., Bischel M., Grunder M., Mool P., 1984. Mapping of mountain hazards and slope stability. Mountain Research and Development 4(3): 247- 266.

Liu J.G., Mason P.J., Clerici N., Chen S., Davis A., Miao F., Deng H., Liang L., 2004. Landslide hazard assessment in the Three Gorges area of the Yangtze River ASTER imagery: Zigui- Badong. Geomorphology 61: 171-187.

Mason P. J., Rosenbaum M.S., 2002: Geohazard mapping for predicting landslides: an example from the Langhe Hills in Piemonte, NW Italy. Quarterly Journal of Engineering Geology and Hydrogeology 35: 317-326.

Owen L.A., Kamp U., Khattak G.A., Harp E.L., Keefer D.K., Bauer M.A., 2008. Landslides triggered by the 8 October 2005 Kashmir earthquake. Geomorphology 94: 1-9.

Pande, A., 1998: Geomorphic Hazard Mapping in Jaigan Watershed. Project report submitted to CSIR, New Delhi under Scientists' Pool Scheme. 159.

Pande A., Joshi R.C., Jalal, D.S., 2002. Selected landslide types in the Central Himalaya: their relation to geological structures and anthropogenic activities. The Environmentalist 22: 269-287.

Pande A., 2013. Jogyura Landslide: Impact of Main Boundary Thrust, A Case Study from Central Himalaya, India. In: C. Morgottini, P. Canuti, K. Sassa (eds.), Landslide Science and Practices. Springer-Verlag Berlin Heidelberg, 1: 595-600, DOI 10. 1007/978-3-642- 31325-7-78.

Rautela P., 2001. August, 1998 landslide tragedies of Central Himalayas (India): learning from experience. International Journal Environmental Studies 58(3): 343-355.

Sah M.P., Mazari R.K.,1998. Anthropogenically accelerated mass movement, Kulu Valley, Himachal Pradesh, India, Geomorphology 26(1-3): 123-138.
Sah M.P., Mazari R.K., 2007. An Overview of the Geoenvironmental Status of the Kullu Valley, Himachal Pradesh, India. Journal of Mountain Science 4(1), 3-23.

Sato H.P., Harp E. L., 2009. Interpretation of earthquake-induced landslides triggered by the 12 May 2008, M7.9 Wenchuan earthquake in the Beichuan area, Sichuan Province, China using satellite imagery and Google Earth. Landslides 6: 153-159.

Sharma V.K., 2006: Zonation of landslide hazard for urban planning-case study of Nainital town, Kumaun Himalaya, India, IAEG, Paper number 191, The geological society of London, $1-6$.

Starkel L., 2010: Ambootia landslide valley-evolution, relaxation and prediction (Darjeeling Himalaya). Studia Geomorphologica Carpatho-Balcanica 44: 113-131.

Strahler A.N., 1952: Hypsometric (area-altitude) analysis of erosional topography. Bulletin of Geological Society of America 63: 117-1142.

Strahler, A.N: 1964: Quantitative geomorphology of drainage basin and channel networks: In: V.T. Chow (ed.) Hand book of applied hydrology, Mc Grow Hill, New York, pp 4-11.

Singh R. B., 1998: Land use cover changes, extreme events and ecohydrological responses in the Himalayan region. Hydrological Processes 12: 2043-2055.

Tarantino C., Blond A. P., Pasquariell O, G., 2007. Remote sensed data for automatic detection of land-use changes due to human activity in support to landslide studies. Natural Hazards 41: 245-267.

Valdiya K.S., 1980. Geology of Kumaun Lesser Himalaya, Wadia Institute of Himalayan Geology, Dehradun.

Valdiya K.S., 1985. Accelerated erosion and landslide prone zone in the Central Himalayan Region. In: Singh, J.S. (ed) Environmental Regeneration in Himalaya Gyanodaya Prakashan, Naini Tal: 12-33.

Valdiya K.S., 1987. Instability of hill slopes and landslides In: K.S. Valdiya (ed.) Environmental Geology - Indian Context. Tata McGraw Hill, New Delhi: 269 - 315.

Van Westen C. J., Castellanos E., Kuriakose, S. L., 2008. Spatial data for landslide susceptibility, hazard, and vulnerability assessment: An overview. Engineering Geology 102: 112-131.

Yin Y. P., Wang F. W., Sun P., 2009. Landslide hazards triggered by the 2008 Wenchuan earthquake, Sichuan, China. Landslides 6: 139-152.

Zimmerman M., Bischel M., Kienholz H. 1986: Mountain hazards mapping in the Khumbu Himal, Nepal with prototype map, scale: 1:50,000 Mountain Research and Development 6(1): 29-40. 